\title{
Lapurdum
}

Euskal ikerketen aldizkaria | Revue d'études basques |

Revista de estudios vascos | Basque studies review

$11 \mid 2006$

Numéro XI

\section{Bernardo Atxagaren Soinujolearen semea (I) : nazioari mugak non ezarri erabakitzearen ezinezkotasuna}

\section{Gorka Mercero Altzugarai}

\section{(2) OpenEdition}

1 Journals

\section{Édition électronique}

URL : http://journals.openedition.org/lapurdum/359

DOI : 10.4000/lapurdum.359

ISSN : 1965-0655

Éditeur

IKER

\section{Édition imprimée}

Date de publication : 1 novembre 2006

Pagination : $241-270$

ISBN : 978-2-86781-474-7

ISSN : $1273-3830$

Référence électronique

Gorka Mercero Altzugarai, «Bernardo Atxagaren Soinujolearen semea (I) : nazioari mugak non ezarri erabakitzearen ezinezkotasuna », Lapurdum [Linean], 11 | 2006, Sarean emana----an 01 avril 2008, kontsultatu 21 décembre 2020. URL : http://journals.openedition.org/lapurdum/359 ; DOI : https:// doi.org/10.4000/lapurdum.359 


\title{
Bernardo Atxagaren Soinujolearen semea (I): nazioari mugak non ezarri erabakitzearen ezinezkotasuna ${ }^{1}$
}

\author{
Gorka MERCERO ALTZUGARAI
}

\section{Aitzinsolasa: literatur kritikaren ezinei eta ahalei buruz}

$[\mathrm{N}]$ ahiz eta "literatura" deituriko fenomenoa historikoki Europan agertu, halako eta halako unean, honek ez du esan nahi objektu literarioa modu zorrotzean identifika daitekeela. Ez du esan nahi literaturaren esentziarik dagoela. Are kontrakoa ere esan nahi du.

Jacques DERRIDA, "This Strange Institution Called Literature"

Arrazoi ugari daude Soinujolearen semea nobela aparta dela baieztatzeko: klasizismoaren linealtasuna eta modernismoaren zatikakotasuna dotorezia handiz bateratzen dituen egitura doi eta sendoa, ahalegin deskribatzaile oro hutsal bihurtzen duen aberastasun tematikoa, zehaztasun txundigarriaz bilbaturiko argumentua edota zertan-datzan-ez-dakigun baina hain Atxagarena den idazkera literario gozagarri hori aipa litezke beste askoren artean. Nobela hau, ordea, hori guztia baino askozaz ere gehiago da. Batetik, Soinujolearen semea egilearen hogeita hamar urtetako ibilbide sortzailearen zinezko summa literaria da, Obabako zikloaren sintesia, azken hitza eta hitz gorena. Gailentasun hau berau arrazoi nahikoa izan beharko litzateke edozein kritikari ezgai sentiarazteko Soinujolearen semea den hori bere osotasunean atzeman eta adierazteko egitasmoaren aurrean. Bestetik, itxura batean hutsala baina aldi berean erabakigarria den moduan esateko, Soinujolearen semea literatura da, eta pentsabide postestrukturalistak erakutsi legez ez dago literatura den hori ezein diskurtso kritiko-analitikoren metodo eta emaitzetara makurtzerik. Literatura, beti ere, hari buruz esan dezakegun guztia

1 - Artikulu hau Eusko Jaurlaritzaren Hezkuntza, Unibertsitate eta Ikerketa Sailak emandako doktoregoaurreko beka bati esker idatzi ahal izan da. 
baino askozaz ere gehiago da. Iruzkin hau, beraz, umiltasunetik eta ezgaitasun kontzientziatik abiarazi beharko da, Soinujolearen semea den joritasun intelektual eta artistikoa erabat atzeman eta adierazterik ez dagoelako kontzientziatik, alegia: beste gai askoren artean 'traizioaz' ari den nobela honetara hurbiltzean, iruzkingilea ere kondenatua dago 'traduttore, traditore' esaera italiarrak itzultzaileei egozten dien hutsa errepikatzera.

Ondorengo orrialdeok burutuko duten 'traizio' edo hutsaz haraindi, hemen literatur ikasketak baliotsuak izan daitezkeelako ideiari eutsi nahi zaio. Argi dago literatur teoria eta kritika ez direla gaurdaino gauza izan -eta ez direla gaurgero inoiz ere gauza izango- literaturaren esentzia atzemateko, errusiar formalismoaz geroztik literaturtasuna deitzen dugun hori zedarritzeko, hots, beren asmo nagusia betetzeko. Honek, halere, ez du zertan berekin ekarririk literatur teoria eta kritika bertan behera uzteko deliberoa. Egun, literaturaren esentziaz eta literatur teoria zein kritikaren betebeharrez aritzean, ezinbestekoa da postestrukturalismoak edota dekonstrukzioak auzi honetara ekarri duten ikuspegi berrira jotzea. Errealitatea ez da esentziala: horixe da 'esentzialki' postestrukturalismoak edota dekonstrukzioak ekarritako ikuspegia. Errealitate esentzial baten ordez, dekonstrukzioak barnediferentziez osaturiko errealitate bat azaleratu du, zeinean izaki edo entitateak 'ixten' edo determinatzen dituzten mugak ekidinezinak diren ibesbideez ere osaturik dauden, izaki edo entitateen bezain berezkoa eginez beren mugetatik kanpoaldean zein barrualdean dagoena. Horrela, entitateak zehatzezinak dira, erabakiezinak, badirena eta ez direna zorrozki mugatzeko modurik ez dagoelarik.

Ikuspegi honen ordezkari nagusienetakoa den Jacques Derrida-rentzat literaturak aparteko garrantzia dauka, hain zuzen ere, entitateen mugak zehatzezinak direla erakusteko duen ahalmenagatik. Literaturaren 'esentzia', nolabait, inon esentziarik ez dagoela erakusteko duen ahalmena litzateke ${ }^{2}$. Honek, ezinbestez eta paradoxikoki bada ere, literaturak ere esentziarik ez duelako ondoriora garamatza ${ }^{3}$. Esentziarik ezean, oso ulertzekoa egiten da literatur teoria zein kritikaren proiektu nagusiak -literaturtasuna zedarritzeko asmoak, alegiaporrot egin izana. Are gehiago, literatur teoria eta kritikak behin eta berriz 'traizioa' baino ezin diote egin literaturari: non dago, bestela, 'leialak' izateko aukera emango liekeen literaturaren balizko esentzia?

Nahi bada, beraz, literaturaren esentziarik ezak literatur teoria zein kritikaren proiektua ikergairik gabe utzi eta porrot egitera kondenatu du. Alta bada, zergatik ez pentsatu -Derrida-k hain usu darabilen arrazoibide-iraulketa eraginez- ezaugarri hori, literaturaren esentziarik ez hori dela, hain zuzen ere, literatur teoria eta kritika ahalbidetu egiten dituena, beren izateko baldintza ezarri egiten duena? Hau da, zergatik ez pentsatu literaturak esentziarik ez daukalako preseski direla beharrezkoak literatur ikasketak? Ez al da orduantxe, hau da, literaturaren esentziaren gaineko galderak -zertan datza literatura?- erantzun erabakigarririk ez duela dakigunean, inoiz baino premiazkoagoa bihurtzen esperientzia literarioa

\footnotetext{
2 - Ikus, kasu, Derek Attridge, 'Introduction: Derrida and the Questioning of Literature', in Derek Attridge (ed.), Jacques Derrida. Acts of Literature (London \& New York: Routledge, 1992), 1-29. orr. (5-6. orr.).

3 - Ibid., 6. or. Mendebaldeko kulturan nagusi ditugun mundu-ikuskera esentzialistek maiz ondorioztatzen dutenaren kontrara, gauza batek esentziarik ez izateak ez du esan nahi gauza hori existitzen ez dela: literatura izan bada, baina ez dauka esentziarik. Zentzu horretan, literatura esentzia bainoago esperientzia litzateke. Bestalde, esentziarik ez hori litzateke diskurtso kritiko-analitikoei galarazten diena testu literarioak zertan dautzan osoki atzeman eta adierazteko ahalmena.
} 
argitzeko, setiatzeko, ezagutzeko saioa? Edo erantzunik gabe utziko dugu bestaldetik begiratuta hain arrunta eta egunerokoa den esperientzia hori ${ }^{4}$ ?

Arrazoibide-iraulketa honen ondorioz irekitzen diren bideetako bat esentzietan beharrean diferentzietan pentsatzera garamatza, hots, esentziak galarazten dituzten zehatzezintasun une edota guneak aurkitzera. Hala, literatur teoriak zein kritikak har dezaketen funtziorik nagusienetakoa diskurtso literarioak errealitatearen barnediferentziak non, noiz eta nola azaleratzen dituen seinalatzean datza. Funtzio hori are garrantzitsuagoa bihurtzen da errealitateari begiratzean esentziak bilatzeko ohitura duen kultura batean, gurean kasu. Atxagari gagozkiola, funtsezkoa da ohartzea zein hurbil dagoen bere mundu-ikuskera zirriborratu dugun antiesentzialismotik. Errealitaterik ez, baizik eta interpretazioak bakarrik daudelako ideia Obabakoak argitaratu baino askoz lehenagotik egon da bere pentsamoldearen erdigunean ${ }^{5}$. Soinujolearen semea Atxagaren summa literaria izanik, ez da harritzekoa bertan ere, ondoren erakutsiko den bezala, antiesentzialismo horrek narrazioaren une erabakigarriak eta nobela osoaren tonua markatzea.

Bi artikulutan banaturik argitaratuko den analisi honek, beraz, Soinujolearen semea-k errealitatean atzemandako barne-diferentziak seinalatzea du helburu nagusia. Lehen artikulu honetan, hizpidea gizabanakoa zein nazioaren zehatzezintasuna izango da, hau da, bata zein bestea zehatz-mehatz zer diren aurresateko eta determinatzeko ezinezkotasuna. Ez dago dudarik nobela honen garrantzi kulturala, hein handi batean, Atxagak bertan islaturiko nazio-ikuskerari zor zaiola. Nazioaren barne-diferentzien inguruko ideiek eguneroko praktika politikoan gero eta presentzia handiagoa dutela esan daitekeen arren, argi samar dago gurean oraindik ere nagusi den nazio-ikuskera esentzialista dela. Atxagak dakarren nazioikuskera, ordea, diferentziala da oroz gain. Esentziak izaki edo entitate zehazgarri eta aldaezinei dagozkie; diferentziak, ordea, -edo barne-diferentziak, hobeki esanaizaki edo entitate zehatzezin eta aldakorrei. Azken hauen modukoa da Atxagaren nazioa, nazio esentziala baino errealago eta premiazkoagoa dena, ondorengo orrialdeotan argudiatuko den bezala. Gizabanakoa ere, bestalde, barne-diferentziez osatutzat jo behar da, nazioa bezain zehatzezin eta aldakorra delarik. Honek, besteak beste, gizabanakoak duen nazioarekiko erantzukizuna ere zehatzezina dela esan nahi du, Soinujolearen semea-k islatu bezala. Modu honetara, Atxagaren nobelak zuzenean eragiten du euskal oroimen kolektibo garaikidearen edukirik garrantzitsuenetako batean, nazioarekiko konpromisoaren etika indibidualean, alegia. Atxaga ez dator etika hori erabat ukatzera, bere zehatzezintasuna azpimarratzera baizik. Izan ere, nazioak ezin du gizabanakoa determinatu gurean etika horrek hain usu egin duen bezain modu zurrun, dogmatiko eta absolutuan.

Jarraian datorren analisi honek, beraz, ez du inondik ere agortzen Atxagaren nobela bikain honen indar adierazlea, baina 'traizio' hau nobelari ahalik eta leialen izateko asmoz eginda dago ${ }^{6}$.

4 - Niall Lucy-k, kasu, hala iradokitzen du: 'Hitz batean, erabakiezintasun printzipioak are kritikoago [are garrantzitsuago, esan genezake guk] bihurtzen du kritiko izatea.' Ikus Niall Lucy, Postmodern Literary Theory. An Introduction (Oxford: Blackwell, 1997), 120. or.

5 - Ideia hau, gutxienez, 1982koa da, Jakin aldizkariko 'Literatura fantastikoa' izeneko artikulu batean agertzen zaigularik jada: ik. Bernardo Atxaga, 'Literatura fantastikoa', Jakin 25 (1982ko Urria-Abend.), 6885. orr. (73. or.). Obabakoak argitaratu zen garaian ideia berbera agertzen duten artikuluetarako ik., besteak beste, 'Bihotzaren inbentarioa', El Diario Vasco. Zabalik (1989-6-7), 5. or.; 'Obabakoak-en gainean', Enseiucarrean 5 (1990eko negua), 11-31. orr. (18-9. orr.).

6 - Lehen artikulu hau Soinujolearen semea-n gizabanakoari, nazioari eta bion arteko harremanari emandako tratamendu ontologikoan zentratzen den bitartean, bigarren artikulua ontologia diferentzial 


\section{'Zergatik egin nuen bat ETArekin?' Erabakiaren unea eroaldia da.}

Izen propioa marka bat da: edozein unetan nahasketa moduko zerbait gerta liteke, izen propioak nahasketa baitarama bere baitan.

1957. urtea, Obabako eskola. Kontakizunak Joseba eta David -soinujolearen semea- aurkezten dizkigu, herriko eta eskolako lagunak, ikasturte-hasierako eszena batean. Berehala, 1999. urtera jauzi egiten dugu. David hil berria da, Kalifornian, bere bizitzako azken hamazazpi urteak osaba Juanen Stoneham arrantxoan igarota. Joseba Stoneham-en hilabete inguruko bisita egiten zegoela gertatu da ezbeharra: David ez da bihotzeko ebakuntza batetik bizirik irten. Hurrengo egunetan, Joseba eta Daviden alarguna Mary Ann-ek hainbat oroitzapen dakartzate gogora. Halako batean, Davidek Soinujolearen semea izenburuaz idatzitako memoriala erakutsi dio Mary Ann-ek Josebari eta Obabako liburutegian uzteko mesedea eskatu. Urtebete geroago, Josebak Kaliforniatik itzuliz geroztik mamituz joandako asmoaren berri eman dio Mary Ann-i: liburu bat egin nahi du Daviden memoriala oinarritzat hartuz. Hortik aurrera badakigu irakurtzen ari garena Josebak egindako berridazketa dela, izen berbera daramana: Soinujolearen semea. Beraz, irakurleak esku artean duen Soinujolearen semea hirukoiztu egiten da puntu honetatik aurrera: lehenik, Bernardo Atxagak sinatzen duen nobela daukagu; bigarrenik, Daviden memoriala; azkenik, Josebaren berridazketa.

Nobelaren egitura narratibo aberats eta konplexuaren ernamuina baino ez den arren, hirutasun honek jada bi galdera-multzo planteatzen ditu nobelaren instantzia narratiboen arteko harremanen gainean. Lehenik, izenburuen arteko ispilu-joko moduko honen bitartez, badirudi Atxagak bide ematen diola irakurleari narratzaileen eta egilearen instantziak identifikatzeko, hots, David edota Josebaren historian Atxagarena berarena ikusteko, hirurek idatzi baitute izenburu bereko liburu bana. Gainera, nobelan zehar Atxagak -berariaz, dudarik gabe- bere biografiaren hainbat zertzelada islatu ditu nahiz Davidengan, nahiz Josebarengan, irakurleari goian aipaturiko identifikazioa oraintxe bai, oraintxe ez iradokiz. ${ }^{7}$ Bada, halere, nobelaren oinarri-oinarrizko ezaugarri bat identifikazio hori airean uzten duena: Atxagak Soinujolearen semea-ren bidez irakurleoi proposatu diguna ez da

horretatik eratortzen diren nobelaren beste bi alderdiri buruz arituko da. Lehenik, nobelan atzeman daitekeen egilea eta pertsonaien arteko identifikazio-joko anbiguoa analizatuko da, identifikazio erabatekoak berariaz ekiditen dituena. Identifikazioen partzialtasun hori errealitate diferentzialaren ondorio ezinbestekotzat hartuko da, testigantzazko nobelagintza postmodernistan gertatu ohi denaren harira. Ildo honetatik, nobelako berariazko identifikazio-anbiguotasun hori harremanean jarriko da nobela idatzi bitartean Atxagak iragarri zuen sinadura-aldaketarekin -Bernardo Atxaga vs. Joseba Irazu-, nobela zein sinadura-aldaketa erabateko identifikazioei ihes egiteko betebehar etiko postmodernoaren instantziatzat hartuko direlarik. Bigarrenik, nobelak gauzatzen duen oroimen kolektiboko egintza JeanFrançois Lyotard pentsalari postmodernoaren anamnesi kontzeptuarekin lotuko da, Soinujolearen semearen oroimen-lanak euskal identitatea orainean zehatz-mehatz determinatu beharrean etorkizunerantz modu irekian proiektatzen duela argudiatzeko.

7 - Soinujolearen semea-rekiko erreferentzietan SS laburdura erabiliko da hemendik aurrera. Biografi zertzeladei dagokienez, Davidek eta Josebak, esaterako, Atxagaren adin bertsua dute (SS, 10. or.); biek ikasi zuten batxilergoa Donostiako La Sallen (SS, 67. or.); Davidek ekonomia ikasketak egin zituen gero (SS, 193. or.); Josebak Bilbon egin zituen bere ikasketa unibertsitarioak (SS, 193. or.); Daviden emaztea itzultzailea da (SS, 32. or.); Davidek bi alaba ditu (SS, 10. or.); Joseba idazle arrakastatsua da (SS, 378. or.); eta abar. 
autobiografi ituna, fikzio ituna baizik. Atxagaren nobelak ez du betetzen, esaterako, genero autobiografikoaren ikerlari nagusienetakoa den Philippe Lejeune-k emandako definizioa: 'Benetako pertsona batek bere bizitzaz kontatzen duen atzera begirako istorioa, zeinean kontalariak bere bizitza pertsonala eta bere nortasunaren historia azpimarratzen dituen ${ }^{8}$ : Soinujolearen semea-n, kontalari edo narratzailea ez da Atxaga bera -autobiografiatzat hartzeko beharko lukeen modura-, ezpada fikziozko narratzaile estradiegetikoa lehenik -Joseba- eta fikziozko narratzaile intradiegetikoa bigarrenik -David-. Gérard Genette-k ohartarazten duen bezala, fikzio itunaren barruan gaudelarik narratzaile estradiegetikoa -Joseba- eta benetako egilea -Bernardo Atxaga- ez dira nahastu behar'. Honen harian, kontakizunaren gertakari nagusienak -David eta Josebak ETAn parte hartzearen ingurukoak, bereziki- ez dagozkio Atxagaren biografiari -Atxagaren biografiaz gutxi gorabehera publikoa den ezagutzaren arabera, behintzat-, eta honek ere oztopatu egiten du arestian aipatu identifikazioa ${ }^{10}$. Edonola ere, badirudi Atxagak bere burua bai kontakizunean agerrarazteko, bai kontakizunetik desagerrarazteko joko moduko horri intentzio osoz ekin diola. Honek, arestian esan bezala, lehen galdera-multzo bat sorrarazten du: zergatik eta zertarako joko hori? Zenbateraino zaigu zilegi David edota Josebaren pentsamolde eta erabakietan Atxagaren itzala ikustea? Ba al da nobelan Atxagaren doblerik? Zenbateraino da Soinujolearen semea nobela autobiografikoa?

Bigarrenik, egitura-ernamuin berberak kontakizuna zein irakurlearen harrera erabat baldintzatuko dituen bikoiztasun narratiboa ezartzen du: Daviden memoriala Josebak berridatzita dago. Irakurlearen harrerari dagokionez, garrantzitsua da ohartzea Josebaren berridazketa aipatua izan aurretik ze nolako igurikimen horizontea zabaltzen zaion irakurleari Daviden memorialari buruz ${ }^{11}$. Nahiz eta Mary Ann-ek Josebari erakustean memorialtzat jo, Davidek idatzitako liburuaren izenburua Soinujolearen semea dela jakin bezain pronto irakurleari zabaldu egiten zaio genero autobiografikoaren gainean dauzkan igurikimenak harrera-prozesura ekartzeko aukera ${ }^{12}$. Irakurle bakoitzak bere igurikimen propioak izango ditu, nork bere kasa ulertuko du zertan datzan genero autobiografikoa. Hortik aurrera, irakurle bakoitzak testuan barneratu ahala bere igurikimenak

8 - Philippe Lejeune, Moi aussi (Paris: Seuil, 1986), 14. or. Hemendik aipatua: Robert Smith, Derrida and Autobiography (Cambridge: Cambridge University Press, 1995), 53. or. Letra etzana eta itzulpena neureak dira.

9 - Gérard Genette, Figuras III (Bartzelona: Lumen, 1989), 285. or. Jon Kortazar ez da iritzi honetakoa: berak Joseba eta Atxaga identifikatu egiten ditu. Ik. Jon Kortazar, "Soinujolearen semea" El hijo del acordeonista, de Bernardo Atxaga', Cuadernos de Alzate 32 (2005, 1. seihilekoa), 119-36. orr. (131. or). 10 - Honezaz gain, Atxagak David zein Josebarengan islaturiko biografi arrastoak ez dira zertzelada txiki batzuk baino, egilea eta pertsonaion arteko identifikazioa inoiz ere ez delarik erabatekoa suertatzen. Gainera, Atxagak proportzio bertsuan banatu ditu zertzelada horiek David eta Josebaren artean, batarekiko identifikazioa ez zaiolarik inoiz ere argiegi gailentzen bestearekiko identifikazioari. Argi dago, beraz, Atxagak David zein Josebarekiko nolabaiteko identifikazioa iradoki nahi izan badu ere, aldi berean ez duela bere burua guztiz identifikatu nahi izan ez bata, ez bestearekin, hau da, berariaz bilatu duela identifikazio-anbiguotasun moduko hori.

11 - Ezaguna denez, Hans Robert Jauss-ek proposaturiko kontzeptu hau bikoitza da: alde batetik, testuak berak hainbat seinale edo arrastoren bidez markatzen duen irakurketa-norabidea adierazten du; bestetik, seinale edo arrasto horiek irakurlearengan aktibatzen dituzten irakurketa-norabidearen gaineko aurreikuspenei dagokie. Kontzeptuaren euskarazko azalpen zehatzago baterako, ik. Mari Jose Olaziregi, Bernardo Atxagaren irakurlea (Donostia: Erein, 1998), 19-21. orr.

12 - Ik. SS, 15. or. Narratzailea benetako pertsona izan dadila eskatzen duen baldintza izan ezik, irakurleak genero autobiografikoaz dauzkan gainerako igurikimen guztiak ekar ditzake harrera-prozesura une honetatik aurrera. David fikziozko pertsonaia izanik, bistan da, irakurleak fikziozko autobiografia bat baino ezin du iguriki. 
egiaztatuta ala ukatuta ikusiko ditu ${ }^{13}$. Edonola ere, irakurgaia Josebak berridatzitako Daviden memoriala dela jakitean, irakurleak honen antzeko gaztigu bat suma dezake: 'Jarraian, Daviden memoriala irakurriko duzu, Daviden autobiografia; kasu eman, baina, zeren eta irakurriko duzuna Josebak apailaturiko bertsioa baita.' Planteamendu hau gutxienez bitxitzat jotzeko modukoa da, igurikimen kontraesankorrak zabaltzen baititu: alde batetik, Daviden bizitza eta nortasunaren historia, hau da, bere nia dagoen modurik fidagarrienean -bere autobiografiaren bidez- ezagutzeko prestatzen gara; bestetik, ordea, lehen igurikimen hau zapuztuz, Daviden kontakizuna desitxura dezakeen Josebaren esku hartzea atzemateko ere prestatu behar gara. Hasierako bitxitasun sentsazioa are zinezko txundidura ere bihurtzen da Daviden liburuan aurrera egin ahala, espero izandako Josebaren esku hartzea ez baita inondik ere atzematen: zertara dator, orduan, instantzia narratiboaren dobletasuna ${ }^{14}$ ? Daviden kontakizunean, hasi eta buka, ez dugu arrazoirik bat ere aurkitzen entzuten ari garena Daviden ahotsa ez dela pentsatzeko: Joseba kontakizunean dago, hor nonbait, baina Daviden presentziak ezabatu egiten du Josebarena. Alabaina, berridazketaren gaineko gaztigua dela-eta, badakigu Daviden ahotsa dagoenik eta garbien entzuten ari garela uste dugun une berean Josebaren ahotsa entzun behar dugula: David kontakizunean dago, hor nonbait, baina Josebaren presentziak ezabatu egiten du Davidena. Planteamendu honek guztiak bigarren galdera-multzo bat sorrarazten du: noren ahotsa da, orduan, hitz egiten diguna? David eta Josebarena, biena batera? Nola uler daiteke, baina, autobiografia batean -Davidenean, alegia- bi ahots batera egotea? Zer gertatzen da orduan subjektu autobiografikoarekin? Zer helburu bilatu du Atxagak instantzia narratiboaren nahasketa horren bidez?

Edonola ere, badirudi hauteman ditugun bi auziok lotuta daudela. Azken auzi honetan, David eta Joseba dira kontakizunean agertu eta kontakizunetik desagertu egiten zaizkigunak, zergatik oso ondo ez dakigula. Gorago jorratu dugun horretan, Atxaga bera da agertu eta desagertu egiten zaiguna. Beraz, dela egilearen instantzia,

13 - Hala gertatuko da, adibidez, Josebari memorialaren berri eman eta berehala Mary Ann-ek kontatzen duenean zein gertakari zehatzek bultzatu zuen David liburua idazten hastera. Humboldt County-ko zuhaitzetan euskal artzainek labanaz egindako marrazkiak -carvingak-ikustera joanda, Davidi, pozik eta hunkituta, giza premia sakon baten froga iruditu omen zitzaizkion marrazki haiek, nork bere marka uzteko, 'hemen egon nintzen' esana uzteko premiaren froga, alegia. Halere, halako batean aurpegia ilundu omen zitzaion Davidi: Uzkudun boxeolaria ikusia zuen marrazki haietako batean, Obabako frankista eta hauen lagunekin elkar hartuta ibilitako hura bera. Ikuskizun horrek eragindako amorrazioak bultzatuta, David biharamunean bertan hasiko zen bere carvinga egiten, hau da, bere memoriala idazten. Ik. SS, 16-7. orr. Irakurle hipotetiko baten sinismena balitz gizabanakoa bakarra dela, hots, gizabanako bakoitza bezalako beste gizabanakorik bat ere ez dagoela munduan, gizabanakoaren bizi-betebeharra bera den horri eustea eta leial izatea dela, eta autobiografia dela, hain zuzen ere, gizabanakoak bere bakartasunari leial izateko duen baliabideetako bat, irakurle horrek autobiografiaren gaineko igurikimenok egiaztatuta ikusiko lituzke goian laburbildu den nobelako eszenan baldin eta interpretazio hau egingo balu: 'Davidek, bere liburua idatziz, bere carvinga marraztuz, berak bakarrik egin zezakeen marka utzi zuen, hau da, bere bakartasuna adierazi. Gainera, bere liburua Obabako frankistei eta hauen lagunei zien amorruak eragina izateak zera erakusten du, Davidek beretzat zeuzkan balio jakin batzuei leial izatearren idatzi zuela memoriala, hau da, bere buruari ere leial izatearren. Bai, dudarik gabe, Davidek idatzi zuena bere autobiografia da.' Irakurle hipotetiko hori, adibidez, Karl Weintraub izan liteke, zeinaren ustez autobiografiak zerikusia daukan 'gizabanako modernoak bere buruaz duen irudiaren osagarri funtsezko batekin, honako sinismen honekin, alegia: gizabanakoa, dena dela ere, banakotasun bakarra da eta bere bizi-betebeharra bere nortasun propioari leial izatean datza.' Ik. Karl J. Weintraub, The value of the individual: self and circumstance in autobiography (Chicago \& London: The University of Chicago Press, 1978), xi. or. Hemendik aipatua: Robert Smith, Derrida and Autobiography, 55. or. Itzulpena neurea da.

14 - Beherago xehetasun handiagoz argudiatuko da Josebaren esku hartzea atzematen ez delako baieztapena. 
dela narratzaileena, badirudi Atxagaren nobelan subjektuaren egonkortasuna -edo, areago, subjektuaren kontzeptua bera ere- kolokan jarria dela: Soinujolearen semea-n subjektua badago eta ez dago, bada eta ez da, aldi berean guztia ${ }^{15}$. Horrezaz gain, badirudi subjektua kolokan jartzeak proiektu autobiografikoa bera ere kolokan jartzen duela. Hau da, posible al da nork bere buruari bere historia kontatzea? Posible al da nork bere buruari nor den azaltzea? Posible al da proiektu autobiografikoa? Azkenik, badirudi hauteman ditugun bi auziok lotuta baldin badaude emango zaizkien erantzunek ere lotuta egon beharko dutela. Hau da, bataren erantzuna besteari emandako erantzunean bilatuko dugu. Zeinetatik hasi, ordea? Gogora dezagun Atxagak proposatu diguna ez dela autobiografi ituna, fikzio ituna baizik. Gogora dezagun itunak errespetatuak izateko eginak daudela. Argi dago, beraz. Atxaga benetakoa da, David eta Joseba fikziozkoak, fikzio itunean gaude: Daviden kontakizunaren nondik norakoetan bilatu beharko ditugu planteatu ditugun galdera guztien erantzuna ${ }^{16}$.

Daviden kontakizuna Izenak deituriko atalarekin hasten da. Daviden bizitza markatu duten pertsonetako batzuei eginiko eskaintza modukoa da, non pertsona horien gaineko hainbat gogoeta eta pasadizo biltzen diren: osaba Juan, Davidek bere infernurako jaitsiera partikularrean izan zuen gidari jakintsu eta arduratua; Lubis, Daviden haurtzaro eta nerabezaroko lagunik hurkoena, Daviden gogoan zauri ireki baten modura betirako geratuko zena guardiek erail zutenetik; Mary Ann, Daviden emaztea eta musa; Liz eta Sara, Daviden alabak, Daviden oroitzapena gorde dezaketenak... David den hori, hein handi batean, pertsona hauengan dago; pertsona hauek dira, hein handi batean, David den hori.

Bigarren atalak -Ikatz-koxkorra izenekoak, alegia- 60ko hamarkadara garamatza eta Daviden haurtzaroaren bukaera eta nerabezaro osoa kontatzen digu. Iniziaziodenbora da Davidentzat, inozentzia pixkanaka galtzeaz batera inguruko errealitatearen kontzientzia hartuz joango baita. Ezagutza prozesu horretan zehar, mundua muga hainbatek zeharkatua dagoela ikasiko du Davidek, bere burua muga bakoitzaren alde batera edo bestera kokatuz doan bitartean, bere nortasuna aurkitzen saiatzen den bitartean ${ }^{17}$. Hasieran, nekazarien antzinako munduaren eta mundu kaletar modernoagoaren arteko mugaz jabetuko da. Daviden joera naturalak nekazarien mundua hobestera bultzatuko du. Mundu hori desagertzear dagoela konturatuta ere, berak nahiago izango du mundu horri ahalik eta indartsuen eutsiz bizi, bizitzen ari dena amets bat baino ez dela dakien arren ${ }^{18}$. Ondoren, gerra zibilaren oihartzun gero eta ozenagoek ametsetik esnaraziko dute. Gerra zibilak Obabako komunitatean ezarri zuen barne-mugak zein indartsu dirauen ohartuko da David, lagunen arteko liskarretan, osaba Juanek kontatutako istorioetan eta Teresak erakutsitako aztarnetan egiaztatuko duen bezala. Muga horrek lagunak eta familia osoak banatzen ditu, baita Davidena bera ere. Daviden aitak frankisten alde egin zuen gerran, baina Davidek ez daki zenbateraino inplikatu zen haiek egindako basatikerietan. Davidek bere jatorria ezagutzeko, bere aita

15 - Mari Jose Olaziregik ere, nobelaren ezaugarri hau azpimarratuz, subjektuaren ezabaketaz hitz egiten du. Ik. Mari Jose Olaziregi, 'Paradisua hatz mamiekin ukituz: Bernardo Atxagaren Soinujolearen Semea', Egan LVII (2005-1/2), 63-76. orr. (65. or.)

16 - Atxagak nobelan duen presentzia anbiguoa erabateko identifikazioei ihes egiteko betebehar etiko postmodernoaren ondorioa dela argudiatuko da beste nonbait. Argudio hori, gorago esan bezala, Soinujolearen semea-ren gaineko analisi honen bigarren parterako utziko da, artikulu honen ondoren argitaratuko den bigarren artikulu baterako, alegia.

17 - Mari Jose Olaziregik dioen bezala, Atxagaren unibertso literarioaren giltzarrietako bat muga kontzeptua da.' Ik. Mari Jose Olaziregi, 'Paradisua hatz mamiekin ukituz', 67. or. 18 - SS, 77-8. orr. 
nolako gizona den egiaztatu ahal izateko bilaketari ekingo dio. Aitagandik urrundu ahala, osaba Juan eta gerrako galtzaileen aldera lerratuko da pixkanaka. Bere jarrerafinkatze progresiboaren araberako erabakiak hartzen ere hasiko $\mathrm{da}^{19}$. Prozesu neketsu baten bukaeran, Davidek ikasiko du bere aitak, beste bidegabekeria batzuen artean, frankistek Obaban egin zituzten fusilamenduetan parte hartu zuela. Aurkikuntza hori unibertsitatera joateko garaiarekin batera helduko da Daviden nerabezaroari bukaera emanez.

Hurrengo atala -Egur pusketa kiskalia, alegia- istorioan lau urte aurrera jauzi eginda hasten da, 70eko hamarkadan jada. Munduak gutxi gorabehera lau urte lehenagoko muga berberetan dirau, nahiz eta muga horietako batzuk doi bat lausotuak egon ${ }^{20}$. Halere, muga berriak agertzen hasiko dira. Alde batetik, Daviden gogoa Virginiarengan jarrita dago erabat, nolabaiteko muga ezarriz David eta gainerako guztiaren artean. Bestetik, lagun berriak etorri dira kanpotik Obabara -Agustin, Bikandi, Jagoba eta Isabel-, talde berri bat osatuko dutenak Lubis eta Josebarekin. Badirudi Davidek, behin mundua zer den eta zer eskain diezaiokeen ikusita, bere tokia -beste edozeren gainetik- Virginiaren alboan dagoela erabaki duela. Obabako jaiekin batera, gertakariak arrapaladan etorriko dira bata bestearen atzetik. David Virginiarekin ateratzen hasi den egun berean agintearen aurkako istilu larriak sortu dira herrian, zeinekin, itxura batean, Obabara etorritako lagunek zerikusia daukaten. Hiru egun geroago, Lubis hilik agertuko da errekan, guardiek diotenez istripuz itota. Biharamunean, Joseba larri-ikaretan etorriko zaio Davidi Virginiaren etxera, Lubis guardiek hil zutela eta Agustin eta enparauak ere arriskuan daudela esatera. Osaba Juanen Iruain baserriko gordeleku ezkutuan sartu beharko ditu denak Davidek.

Azken atalak -Abuztuko egunak deiturikoa, alegia- David hil aurreko azken hilabetera garamatza, 1999. urtera. Joseba Stoneham-en bisitan dagoen bitarteko eguneroko gertakariak Daviden atzera begirako kontakizunarekin tartekatzen dira. Lubisen hilketaren ondoren Daviden bizitzan beste muga bat sortu zela ezagutzen dugu horrela, David eta Joseba ETAn sartzearen ondorioz beraien eta atzean utzitako munduaren artean sortu zen muga, hain zuzen ere. David eta Josebak diktadura bukatuta ETA uzteko hartu zuten erabakiarekin bukatzen da memoriala.

Paragrafootan eskaini den Daviden memorialaren laburpena beharrezkoa zen ondoren datorren argudiaketari testuinguru egokia emateko. Hasteko, azpimarratu beharra dago Daviden kontakizunak seinale erabakigarriak eskaintzen dizkiola irakurleari beronek, behin testu osoa irakurrita, genero autobiografikoaz zituen igurikimenak egiaztatuak ikus ditzan, itxura batean, behintzat. Izan ere, alde batetik, David da -Josebaren berridazketa gorabehera- bere bizitza pertsonaleko gertakariak azpimarratuz lehen pertsonan denbora osoan hitz egiten duena, entzuten den ahotsa Davidena ez dela pentsatzeko arrazoirik bat ere topatu ezin delarik, arestian esan bezala ${ }^{21}$. Bestetik, Daviden nortasunaren historia da -Lejeune$\mathrm{k}$ eskatu bezala- nabarmendua gertatzen dena bere kontakizunean, zeinaren hainbat eta hainbat pasarte Daviden nortasunaren finkatze-prozesuaren

19 - Adibidez, Degrela koronelak osaba Juanen zaldirik gogokoenetako bat bere alabarentzat jauntxokeria hutsez eraman nahi duenean, Davidek lagundu egiten dio Lubisi zaldia koronelaren begi-bistatik ezkutatzen (SS, 114-6. orr.). Halaber, Davidek bere burua ezkutatzea erabakitzen du frankistek Obabako plazan ezarriko duten monumentuaren inaugurazioan akordeoia jo behar ez izateko (SS, 222. or.).

20 - Iruain baserriak, kasu, ez du jada David lehen bezainbeste erakartzen; Davidek ez du jada sentitzen izan dezakeen etxe bakarra Iruain denik (SS, 287-8. orr.). Aitarekiko distantzia ere ez da iritsi espero zitekeen bezain gaindiezina izatera; David, adibidez, soinua jotzen hasiko da Alaska hoteleko igandeetako dantzaldietan aitak hala eskainita (SS, 281-3. orr.). 
adierazgarritzat jo daitezkeen: hor dauzkagu, adibidez, bizitzan zehar Davidek bere kidekotzat aukeratu dituen pertsonak -bere zerrenda sentimentalak, Atxagaren modura esana-; hor, mundua zeharkatzen duten mugez jabetu ahala Davidek alde baterantz edo besterantz lerratzeko erakutsi duen joera; hor, aitaren historian arakatuz Davidek bere jatorria ezagutzeko sentitu duen beharra; hor, bere kontzientziaren arabera hartutako erabaki larri eta arriskutsuak; hor, azkenik, Virginia bilatuz lehenbizi, eta Mary Ann aurkituz ondoren, Davidek infernutik ateratzeko maitasunaren alde egindako aukerak. Autobiografia nork bere nortasunaren historia jasotzeko bidetzat ez ezik, nork bere burua ezagutzeko bidetzat ere jotzen duen irakurleak ere genero autobiografikoaz dauzkan igurikimenak egiazta litzake nobelan, horretarako aukera ematen baitu, esaterako, Davidek Mary Ann-i memoriala zergatik idatzi nahi duen azaltzen dioneko pasarteak. Honelaxe dio Davidek, Mary Ann-ekin bizitzan erabakiak hartzeko izaten diren arrazoiei buruz hizketan ari delarik:

Nik ere hala uste dut, arrazoiak asko izaten direla beti -esan nion-. Horregatik idatzi nahi dut liburua. Kontuak garbitzeko. Badakizu, bizitzanaldaketa bat gertatzen denean, zeremonia behar da. Norbait hiltzen denean ere, ez da sosegurik izaten hileta elizkizuna egin arte. Pentsa ezazu itsasoan ezkutatzen direnen kasuan. Familiakoek asko sufritzen dute gorpua hondartza batean azaltzen den arte. Orduantxe gelditzen dira lasai, lur eman ahal diotenean. $\mathrm{Ba}$, nik ere antzeko zerbait nahi dut. Nire oroimenaren ur ez oso lasaietan dabiltzan kondarrak bildu eta liburu batean gordeta utzi betiko; errauts-kutxa batean bezala. Orduan geldituko naiz lasai $^{22}$.

Davidek ez du bere baitan oso argi ikusten, ez daki oso ondo zein diren bizitzan hartu dituen erabakien zergatiak, ez dago oso lasai bere buruarekin, hitz batean esanda, ez daki oso ondo nor den. Gabezi horiek konpondu eta oreka-erdigune bat lortu nahi du, bere burua aurkitu. Hala interpreta lezake goiko pasartea Christophe Miething-ek, adibidez, zeinarentzat 'autobiografiari galdera bakarra axola zaio[n]: nor naiz ni? [...] Proiektu autobiografikoak Delfoseko orakuluak emandako agindua obeditzen du, hots, gnothi se auton mandatua' ${ }^{23}$.

21 - Memorialean txertaturik agertzen diren ipuinak Daviden ahotsa desitxuratzen ez duten digresiotzat jo behar dira. Hala, Obabako lehen amerikanoa eta Euskadi askatzearen aldeko mugimendua eta Toshiro izenekoen atzean Daviden itzala bakarrik ikusi behar da, ez beste inorena, argi adierazten baita nobelan Davidek berak idatziak direla (ik., hurrenez hurren, SS, 426. or. eta 394-6. orr.). Pirpo eta Txanberlain, biltzaileak izenekoa nork idatzia den hain argi geratu ez arren, Daviden bizitzaren historiarekin zerikusi handirik ez duen digresio narratibotzat jo daiteke, Daviden ahotsaren irmotasunean eraginik ez duena. Memorialean zehar Daviden ahotik beste norbait hitz egiten ari dela atzeman daitekeen une bakarra Josebak idatzitako Hiru aitorpen izeneko atalaren barruan aurkitzen da, Ramuntxoren aitorpena izeneko pasartean, hain zuzen ere. Bertan, Daviden bizitzaren aldi erabakigarri baten nondik norakoak kontatzen dira, hala nola ETAn ez jarraitzeko izan zituen arrazoiak, bere burua poliziari emateko hartu zuen erabakia, ETAn bere kideak izandakoek atxiloketaren ondoren traidoretzat jo zutelako pairatu behar izan zuen ostrazismoa... Hau da, memorialaren zati funtsezko baten berri Josebak Daviden abotan jarritako bitzen bidez ematen da eta honek zalantza sor dezake Josebak Daviden ahotan jarritako gertakarien bertsioa eta Davidena berarena zenbateraino letozkeen bat. Halere, zalantza hori erabat uxatzen da Josebaren kontakizuna bukatu bezain pronto, Davidek kontakizunaren edukiaren gaineko bere guztizko adostasuna adierazten dionean (ik. SS, 455. or.). Beraz, Ramuntxoren aitorpena-n ere entzuten den Daviden ahotsa desitxuraturik ez dagoela baiezta daiteke.

22 - SS, 53. or. Letra etzana neuk jarria da.

23 - Christophe Miething, 'Le grammaire de l'égo: phénoménologie de la subjectivité et théorie autobiographique', in Mireille Calle-Gruber \& Arnold Rothe (ed.), Autobiographie et biographie: colloque de Heidelberg (Paris: Librairie A. G. Nizet, 1989), 149-50. orr. Hemendik aipatua: Robert Smith, Derrida and Autobiography, 55. or. Itzulpena neurea da. 
Edonola ere, tankera honetako interpretazio orok testuaren zehaztapen desegokia burutuko luke, ez bailuke kontuan hartuko hemen dagoeneko hainbat aldiz aipatu den bikoiztasun narratiboa. Davidek testuan duen presentzia erabatekoa izan arren eta irakurleak autobiografiez dauzkan igurikimenak testuan gauzaturik ikusteko aukera izan arren, Joseba mamu baten modura dabilkio segika irakurleari, behin eta berriro eraginez goian planteatu ditugun zalantza eta galdera guztiak, funtsean honako honetara biltzen direnak: zer zentzu dauka narratzailearen bikoizketak Soinujolearen semea-n? Hemen proposatuko den erantzunak Harrera Estetikaren kontzeptu giltzarrietako batean du abiapuntu, Wolgang Iser-ek Roman Ingarden-en ideiak oinarritzat hartuz garaturiko butsuneen kontzeptuan, hain zuzen ere $^{24}$. Labur esanda, Iser-en ideia da testu literarioek ezinbestez agertu behar dituztela hutsune semantikoak beren egituraketan, beren berezko izaera baita dendena ezin kontatu ahal izatea. Hutsune horiek, zenbaitetan, ezustekoak, zalantzak edota igurikimen horizontearen berrantolaketak eragiten dituzte irakurlearengan. Hutsune horiek dira, halaber, testuak izan ditzakeen irakurketa anitzen eragileak, irakurle bakoitzak bere modura bete beharko baititu testuaren zehaztapena lortuko badu $^{25}$. Soinujolearen semea-n ere bada ezustekoa, zalantza eta igurikimen horizontearen berrantolaketa eragiten dituen hutsune nabarmen bat, nobelaren harrerarako guztiz erabakigarria suertatuko dena, gainera. Izan ere, irakurleak hutsune hori betetzeko aukeratzen duen moduaren arabera nobelaren zehaztapen zeharo ezberdinetara ailegatzen baita.

Daviden kontakizunean bada etete-, eraldatze- eta geroratze-une funtsezko bat, irakurleari oharkabean pasa ezin zaion zinezko inarroste narratibo bat, kontakizunaren ordura arteko konfigurazioa goitik behera iraultzen baitu. Une hori Egur pusketa kixkalia eta Abuztuko egunak izeneko atalen arteko trantsizioarena da. Egur pusketa kixkalia-k eta bere aurreko atalak -hots, Ikatz-koxkorra izenekoak- batasun narratibo garbia osatzen dute, zeinean Daviden haurtzaroaren amaiera, nerabezaro osoa eta 1970eko udako gertakari iraultzaileak kontatzen zaizkigun. Luzeran behintzat nobelaren gorputz nagusia den honetara behin analepsi baten bidez sartu ondoren, kontakizunak guztiz modu linealean aurrera egiten du, harik eta 1970eko uda-amaierako gertakari larriak azaldu arte ${ }^{26}$. Hain luzaroan eutsi zaion analepsi hori eten egiten da Abuztuko egunak-en sartzearekin bat: kontakizunak 1999ko abuztura garamatza berriro, Daviden orainera, alegia; horrela, kontaketa-ekintzaren denborak eta kontaturiko istorioarenak bat egiten dute. Une honetatik aurrera, Daviden kontakizunak -aurreko gorputz narratibo luzean ez bezala- iraganeko kontuak ez ezik, oraineko gertakariak ere hartzen ditu hizpide: Josebaren bisita, Mary Ann-ekiko elkarrizketak, alabekiko liskartxoak... Horrela, Daviden memorialak -bere itxura eraldatuz- egunkari forma hartzen du. Baina, oroz gain, trantsizio tarte honek eragiten duen efekturik nabarmenena akzio narratiboaren geroratzea da, akzio hori bere intentsitatearen gailurrean zegoen une berean, gainera: Egur pusketa kixkalia David kinka larriko une batean zegoela bukatzen da, Agustin -Triku-, Jagoba -Papi- eta gainerakoen bila abiatzen denean guardien jazarpenetik ihes egiten laguntzera; Abuztuko egunak-en hasierarekin batera kontakizunak akzioari jarraipen narratiborik eman gabe 1999. urtera jauzi

24 - Ik., esaterako, Wolfgang Iser, 'El proceso de lectura: enfoque fenomenológico', itzul. Eugenio Contreras, in José Antonio Mayoral (ed.), Estética de la recepción (Madrid: Arco, 1987), 215-43. orr. 25 - Ibid., 222-3. orr.

26 - Ikatz-koxkorra-k eta Egur pusketa kixkalia-k hirurehun orrialdetik gora hartzen dute, gutxi gora behera nobelaren luzeraren bi heren. Linealtasunari dagokionez, egia da bi atalon artean bi ipuin txertatzen direla, baina ipuin horiek digresiotzat jo eta beste maila diegetiko batean kokatu behar dira, ez Daviden memorialarenean. 
egiten duenean, kinka larriko une haren ondoko gertakari oro elipsi narratibo ia erabateko batean murgiltzen dira, zeinetatik zertzelada txikitan baino ez diren azaleratzen joango. Zertzeladari zertzelada, azkenean David ETAn sartu zela egiaztatzera heltzen gara, baita Triku eta Josebarekin -Etxeberriarekin- batera komando bat osatu zuela ere. Hortik aurrera eta erritmo narratiboa berreskuratu ahala, kontakizunak hiru kide hauek poliziaren eskutan erori arte ETAren barruan egin zuten ibilbidearen berri ematen du.

Inarrosaldi narratibo moduko honetatik igarotzearen ondorioz, aipatu berri dugun elipsia guztiz azpimarraturik geratzen da kontakizunaren puntu honetatik aurrera. Izan ere, elipsiak isilduriko gertakariak ez dira inoiz zeharo argitara ekartzen, bereziki David Papiren taldeari laguntzera joaten denetik bera ere organizatuta egotera heldu bitarteko guztiak. Kontakizunak ez du inoiz argitzen noiz, nola eta zergatik sartu zen David ETAn. Kontakizunak Davidek uneren batean ETAn sartzeko hartu behar izan zuen erabakia ezkutatzen $d^{27}$. Hauxe da goian seinalaturiko butsune erabakigarria, galdera honetan jaso daitekeena: zergatik erabaki zuen Davidek ETAn sartzea? Gogora bedi Davidek, hain zuzen ere, kontuak garbitzeko idatzi duela memoriala, bizitzan hartu dituen erabakien arrazoiak argitzeko alegia, goian transkribatu den pasartean Mary Ann-i adierazi bezala. Beraz, Daviden erabakiaren gaineko azalpenen bat espero duenean preseski, irakurleak ezustean hutsune hau baino ez du topatzen, zeinak zalantza ere eragiten dion: zergatik ez dizkigu Atxagak Daviden erabakiaren nondik norakoak erakutsi? Honezaz gain, kontakizunaren puntu honetaraino irakurleak nola edo hala bete ahal izan dituen autobiografiaren gaineko igurikimenak -hots, autobiografia nork bere burua azaldu, ulertu edota ezagutzeko bidetzat jotzen duten horiek- ukatuak gertatzen dira hutsune honen agerpenarekin batera. Horrela, distantzia estetiko nabarmena sortzen da testua eta irakurlearen igurikimenen artean, zeina txikitu edo are ezabatu ere egin ahal izango den planteatu berri diren galderei ematen zaien erantzunaren arabera, hau da, hutsunea betetzeko irakurleak egiten dituen aukeren araber $^{28}$. Horregatik da hutsune hau guztiz erabakigarria Soinujolearen semea-ren harrerarako.

ETAn sartzeko erabakia isilduz, kontakizunak beste efektu bat eragiten du, irakurlearen atentzioa Davidek Papiren taldeari laguntzea erabaki zuen unera bideratzea, hain zuzen ere $^{29}$. Izan ere, bigarren erabakiaz -bigarrena kronologiaren arabera- irakurleak ez daki jatorria edo lehen bultzada lehen erabakian izan zuela baino, hau da, Davidek Papiren taldeari laguntzea erabaki zuen unean hasi zela David organizatuta egotera eramango zuen gertakari ezezagunen segida. Hau da, bi erabakion artean nolabaiteko kausa-efektuzko harremana ezarriz eta metonimikotzat jo genezakeen kontaketa-modu batez baliatuz, ETAn sartzeko

27 - Davidek Papiren taldeari laguntzea erabaki zuenean ez zen ETAn sartzeko erabakia hartzen ari: bi erabakiok ezberdindu egin behar dira. Joseba larriturik laguntza eske etorri aurretik, Davidek susmoak izan zituen hainbat aldiz Papi eta gainerakoak ETAn sartuta egon zitezkeela (ik. SS, 327, 357 orr.). Hala ere, berak ez zuen inoiz asmorik agertu taldearekin bat egiteko: berak Virginia besterik ez zuen gogoan (SS, 329. or.). Joseba datorkionean ere, hala esaten dio beroni, Virginiarekin egon nahi duela (SS, 372. or.). Beraz, Davidek Papi eta gainerakoak laguntzen baditu ere, ETAn sartzeko asmoak gidaturik bainoago haien egoera benetan larria delako da.

28 - Hans Robert Jauss-ek proposaturiko distantzia estetikoaren kontzeptuak, hain zuzen ere, publikoaren igurikimenak eta berauek testuan duten gauzatzearen arteko distantzia adierazten du. Ik. Hans Robert Jauss, La literatura como provocación, itzul. J. Godo (Bartzelona: Península, 1976), 174. or.

29 - Azalpen hau neketsu bihur dezaketen adierazleak saihestearren -hala nola Davidek Papiren taldeari laguntzeko hartu zuen erabakia, Davidek ETAn sartzeko hartu zuen erabakia, eta abar- hemendik aurrera erabakiok aipatzeko kronologiaren araberako adierazleak ere erabiliko dira, honela: Papiren taldeari laguntzeko erabakia lehen erabakia izango da; ETAn sartzekoa, bigarren erabakia. 
erabakiaren ordez -efektua- Papiren taldeari laguntzeko erabakia -kausa-kontatzen digu Atxagak ${ }^{30}$. Ordezkapen honi begiratuta, badirudi Atxagak lehen erabakiaren nondik norakoak arrastoen modura taxutu nahi izan dituela irakurleak bigarren erabakiari tankera hobeto har diezaion. Edonola ere, bigarren erabakiaren inguruan goian planteaturiko galderek lehen erabakiaren nondik norakoetan baino ez dute erantzunik aurkituko, beste ezein xehetasunik ez baita inon jakitera ematen.

Lehen erabakiari dagokionez, oroz gain, zirkunstantziak azpimarratu behar dira, erabakia hartzen deneko larrialdi eta eroaldi giro hori, alegia. Berez, erabakirik hartzeko denborarik ez balego bezala gertatzen da guztia: Josebak ikara batean Davidi kontatzen dionez, guardiek hil dute Lubis, atzeman eta torturatu ondoren; orain, Papi eta bere taldekideen bila ari dira bailara arakatzen; ihes egitea hil edo biziko kontua da hauentzat, atxilotuak eta torturatuak izan baino nahiago baitute tiroketa batean hil; Iruaingo gordelekuan ezkutatzea dute irtenbide bakarra; David da aukera seguruena Iruain bitarteko guardien kontrolak arazorik gabe pasa eta gordelekua non dagoen erakusteko ${ }^{31} \ldots$ Zirkunstantzia hauetan, Davidek ez zeukan aukerarik, ez zeukan erabakitzerik: Josebak jaulki zion bezala, Davidek joan beharra zeukan, bestela denak hilko zituzten-eta ${ }^{32}$. Hura ez zen egoera patxadaz aztertu ondoren erabaki bat hartzeko unea, zirt edo zart egitekoa baizik. Hala egin ere, Davidek. Beraz, zirkunstantziek ezinbestez bultzatuta hartu zuen Davidek lehen erabaki hura, zirt edo zart egite horri erabakia deitzerik baldin badago, behintzat. Gauzak horrela, eta kontaketa-modu metonimikoa gogoan hartuta, zer adierazi nahi zaio irakurleari lehen erabakiaren nondik norako hauen bidez Davidek ETAn sartzeko uneren batean hartu behar izan zuen beste erabaki horretaz? Hau bezala, zirkunstantziek ezinbestez bultzatuta hartu behar izan zuela? Honetan bezala, ez zuela egoera patxadaz aztertu ondoren erabaki lasaiago bat hartzeko betarik izan? Une honetan bezala, zirt edo zart egin behar izan zuela ETAn sartzerakoan? Bigarren erabakiaren zirkunstantziak guztiz ezezagunak diren arren, ez dirudi Davidek ETAn sartzekoa bezain erabaki pisua hain berehala, halako larritasun egoera batek bultzatuta edota halako ezinbestekotasunez hartu behar izango zuenik. Hala balitz ere, horrek ez luke argituko zergatik kontatzen diren lehen erabakiaren nondiko norakoak xehetasun osoz eta zergatik isiltzen diren bigarrenarenak erabateko elipsi batean. Bi erabakiok nolabait lotuta dauden arren, ez dira erabaki bera.

Argi dirudiena da nobelaren harrera erabaki-ekintzaren gainean Atxagak taxuturiko gogoetaren baitan dagoela: erabakitzeko aukerarik ematen ez duten egoerak, elipsi batean murgildutako erabakiak, memorial bat idatziz argitu nahi diren erabakiak... Erabaki-ekintzaren nabarmentze hau da, hain zuzen ere, Jacques Derrida-ren pentsamendura jotzera garamatzana puntu honetan, Soinujolearen semea-k eginarazi dizkigun galderei erantzun egokiak aurkitzeko asmoz. Erabakiekintzaren inguruko gogoetak Derrida-ren lanaren azken aldiari oinarria eta batasuna eman dio, erabakiezintasunaren nozioaren bidez, hain zuzen ere. Erabakiezintasunaren nozioak erabaki-ekintzaren barne-logikan bertan aurki daitekeen bideraezintasuna adierazten du. Gure eguneroko logikan, erabakia egoera jakin baten aurrean eginiko analisi arrazionalari jarraituz egindako aukeratzat jo ohi da: egoera baldintzatzen duten datuak bildu, analizatu eta aukera

30 - Berriro ere, honek ez du esan nahi Atxagak bi erabakiok berdindu egiten dituela, baizik eta harreman metonimikoan jarritako bi gauzaren artean gertatu ohi denez, non elkarrekin duten nolabaiteko harremanari esker bata izendatzeko bestea izendatu ahal den, bigarren erabakia kontatzeko lehena kontatzen duela Atxagak.

31 - SS, 370-3. orr.

32 - Ibid., 371. or. 
bakoitzaren abantailak eta desabantailak kontuan hartzearen baitan egon ohi da erabakitzearen ekintza. Honezaz gain, erabakitzearen ideia aukerarik bat ere egitea zail bihurtzen duten egoerei aplikatu ohi zaie, hau da, zalantzazko egoerei, aukerarik garbiena zein den ikustea hein handi batean eragozten duten egoerei. Zentzu honetan, erabakitzearen ideiak berak nolabaiteko erabakiezintasuna barne hartu ohi $\mathrm{du}^{33}$. Edonola ere, eguneroko logikan erabakitzearen ideia zalantzazko egoera bat gaindituz aukerarik onenera heltzea ahalbidetzen duen arrazoitzeprozesuarekin lotu ohi da. Bestalde, gure kulturaren oinarri funtsezkoenetakoa den subjektu kontziente, arrazoidun eta beregainaren ideia subjektuari egokitu ohi diogun erabakiak hartzeko ahalmenean islatzen da besteak beste, hots, subjektuaren erabakimenean: subjektutasuna, hein handi batean, erabakimenean datza.

Derrida-k, berez, ez du erabakia ulertzeko modu ohiko honetan aldaketa sinple bat baino eragiten, baina bere sinpletasunean aldaketa hori txundigarria ere gertatzen da, erabaki-ekintza ulertzeko modu guztiz bestelako batera eramaten baikaitu. Derrida-k dioenez, 'erabaki posible bakarra, hain zuzen ere, ezinezko erabakia da ${ }^{34}$. Zalantza guztiak uxatzen dituen arrazoitze-prozesuaren ondorioz hartzen den erabakia ez da erabakia, hasieran ezagutzen ez zen erantzunera heltzea ahalbidetu duen programa, kalkulu edota erregelaren aplikapen hutsa baizik. Erabakia, hain zuzen ere, arrazoiak programa, kalkulu eta erregela guztiak agortuta ere erantzun garbirik eman ezin izan duenean egin beharreko aukera da. Beraz, erabakia arrazoiaren eremutik haratago dagoen eremuari dagokio, erabakiezintasunaren eremuari alegia. Ikus daitekeenez, erabakiaren barne-logikak berak egiten du erabakia ezinezko: arrazoiak zalantza guztiak uxatuta lorturiko emaitza ez da erabakia, erregela baten ondorio hutsa baizik; baina arrazoiak zalantzak uxatzen ez baditu, zirt edo zart egite hori ere ez da erabakia, galdua baitu erabakitzearen ideiaren funtsa, hau da, arrazoiaren ondorioa izatea, hain zuzen ere $^{35}$. Hau guztia Søren Kierkegaard filosofoaren aipu bat eginez laburbildu ohi du Derrida-k, dagoeneko dekonstrukzioaren lelo ezagunenetakoa bihurtu den esaldi honetan: 'erabakiaren unea eroaldia da' ${ }^{36}$.

Beraz, erabakia arrazoibide ororen eremutik haratago gertatzen da, gertatzen den horri erabakia deitzerik badago, behintzat. Honek, bistan da, arrazoiaren kontzeptu tradizionala ez ezik, subjektuari egokitu ohi zaizkion ahalmenak ere zuzenzuzenean murrizten ditu, subjektuaren erabakimena, kasu. Erabakimena ez da gehiago subjektuaren baitako ahalmena, erabakia subjektuaren erabakitzeko ahalmenetik haratago gertatzen baita, arrazoiaren kasuan lez: erabakia subjektuaren baitan ez dagoenaren baitakoa da. Beraz, Derrida-k dioen bezala, 'ez dago subjektuaren ezein teoriarik erabakirik txikiena ere azaltzeko gai izango denik ${ }^{37}$. Bestela esanda, subjektuak ezingo du inoiz harturiko erabakia guztiz justifikatu. Hala eta guztiz ere, subjektuarengan gertatzen jarraitzen du erabaki

33 -Euskarazko zirt edo zart egin esamoldea, adibidez, zalantza handiko egoerekin loturik erabili ohi da. 34 - Frantsesezko jatorrizkoan: '[1]a seule décision possible, c'est la décision impossible.' Ik. Jacques Derrida \& Anne Berger, ' "Dialangues »', elkarrizketa, in Elisabeth Weber (ed.), Jacques Derrida. Points de suspension. Entretiens (Paris: Galilée, 1992), 141-65. orr. (157. or.). Itzulpena neurea da.

35 - Erabakiaren gaineko Derrida-ren ideiak bere obran zehar sakabanaturik samar daude, askotan beste gai konplexuago batzuen analisietan tartekatuta. Derrida erabakiaren gaiari lotzen zaion pasarterik garbienetako baterako ik. Jacques Derrida \& Anne Berger, '" Dialangues »', arestian aipatua, 155-7. orr. 36 - Frantsesezko jatorrizkoan: 'L'instant de la décision est une folie.' Ik., adibidez, Jacques Derrida, Force de loi. Le "fondement mystique de l'autorité " (Paris: Galilée, 1994), 58. or. Euskarazko itzulpena neurea da. 37 - Frantsesezko jatorrizkoan: 'Une théorie du sujet est incapable de rendre compte de la moindre décision.' Ik. Jacques Derrida, Politiques de l'amitié (Paris: Galilée, 1994), 87. or. Itzulpena neurea da. 
orok, non bestela? Erabakimena dekonstrukzio-ondoko subjektuaren ahalmena da oraindik ere, subjektu horrek erabakiak hartzen jarraitzen baitu -jarraitu bebar baitu-. Hau da, subjektuak harturiko erabakia nolabait berarena da; baina berarena da bere baitakoa izan gabe, berarena izan gabe, beste(a)rena izanda, alegia. Simon Critchley-k honelaxe laburbiltzen du paradoxa gaindiezin hau: beste(a)ren erabakia niregan hartzen $d a^{38}$. Honek guztiak, jadanik, subjektua bere baitara osoki bil ezin daitekeela erakusten digu, subjektuaren bezain berezkoa dela bere mugetatik kanpoaldean zein barrualdean dagoena -erabakia kanpoaldekoa izanik barrualdekoa da-, subjektua zedarritzen duten mugak zorrozki zehazterik ez dagoela, subjektua ez dela bera bakarrik, beste(a) ere badela ${ }^{39}$. Honek guztiak, jadanik, errealitatea argi eta garbi zedarrituriko mugetara errenditzerik ez dagoela erakusten digu. Honek guztiak, jadanik, errealitatea zehatzezina, erabakiezina dela erakusten digu.

Soinujolearen semea-ren gaineko analisira itzuliz, gogora dezagun Daviden bigarren erabakia dela -hots, ETAn sartzekoa- irakurleok bete behar dugun kontakizunaren hutsune nagusia. Gorago esan den bezala, ez dirudi David lehen erabakia hartzera behartu zuen ezinbestekotasun berberak bultzatuko zuenik bigarren erabakia hartzera, hau da, ez dirudi Davidek ETAn sartzera derrigor behartuko zuen ezein programa, erregela edo kalkulu onartuko zuenik ${ }^{40}$. Ikusi dugunez, Derrida-ren analisian programa, erregela edo kalkulu baten ondorioa ez den erabaki oro ezinbestez sartzen da erabakiezintasunaren eremuan. Davidek, beraz, erabakiezintasunaren erdigunean hartu behar izan zuen ETAn sartzeko erabakia. Derrida-ren analisiari jarraituz, Davidek ETAn sartzeko erabakia hartu zuela esan beharrean, hauxe esan beharko genuke: ETAn sartzeko erabakia Davidengan hartu zen. Hauxe izan daiteke Atxagak Daviden bigarren erabakia elipsi batean murgilduz adierazi nahi izan diguna. Hipotesi hau kontakizunean bertan egiaztatu beharko litzateke, lehen erabakiaren nondik norakoetan hain zuzen ere, Atxagak -lehen esan bezala- bigarren erabakiaren unea zuzenean kontatu beharrean, zeharka kontatzea erabaki baitu -metonimikoa deitu dugun kontaketamodua baliatuz- lehen erabakiaren nondik norakoetan utzitako hainbat arrastoren bidez.

Hasteko, lehen erabakiaren nondik norakoek Davidek ETAn sartzeko zein ez sartzeko bezain arrazoi hertsakorrak izan zituela iradokitzen dute, hau da, ETAn sartzeko erabakia erabakiezina izan zela, alegia. Alde batetik, David ez zen ETAn ezinbestez sartu, baina ezinbestez abiarazi zuen ETAn sartzera eramango zuen

38 - Ingelesezko jatorrizkoan: the other's decision is made in me. Ik. Simon Critchley, 'The Other's Decision in Me (What Are the Politics of Friendship?)', in Christopher Norris \& David Roden (ed.), Jacques Derrida, 4 ale (London: Sage Publications, 2003), IV, 86-116. orr. (107. or.)

39 - Beste (a)ren nozio postestrukturalista edo dekonstruktiboak edozein entitateren mugetatik kanpo egonda barruan ere badagoen hori adierazteko erabili ohi da, mugak zehatzezin bihurtzen dituen bori, alegia, zeina, bera ere, zehatzezina den. Ingelesez, the other/other erabili ohi dira zehatzezina den borren adierazle bezala: the other of language/language's other, kasu. Euskararen mugagabeak oso egokia dirudi zehatzezintasun nozio hori adierazteko: lengoaiaren beste, adibidez. Nahiz eta azken hau erabilera normalena ez izan, mugagabea darabilten hainbat euskal esamolderen antza har lekioke: bestek esan du; nork bere buruaz beste egin, eta abar. Bestalde, postestrukturalismo zein dekonstrukzioan, beste delako horren nozioa zentzu mugatuan erabiltzen da hainbat kasutan, bestea adieraziz. Adibidez, gizabanakoaren bestea, hots, beste edozein gizabanako, gizabanakoaren mugak zehatzezin bihurtzen dituen beste zehatzezinaren instantzia konkretua da: zuk bihurtzen nauzu zehatzezin, zuk zeuk, zeu ere zehatzezina izanik. Bestea, alegia. Hemen, beraz, beste(a) aukeratu da adierazle orokor modura, zentzu mugagabea zein mugatua adierazteko ahala bilduz esamolde bakar batean.

40 - Kontakizunak bigarren erabakiaren arrazoiak ez agertzeak berak arrazoiok lehen erabakiarenak baino ilunagoak, azaltzen zailagoak direla pentsaraz dezake, hau da, bigarrenekoak ez direla lehenekoak bezain argiak edo, hain zuzen ere, bezain erabakigarriak. 
prozesua, ezinbestez hartu behar izan baitzuen Papiren taldeari laguntzeko erabakia. Prozesu hori elipsi batean guztiz ezkutaturik egoteak galarazi egiten du Daviden bigarren erabakia lehen erabakiaren ezinbestekotasun berberaz hartu zela baieztatzeko aukera -irakurleok, besterik gabe, ez dakigu zer gertatu zen-; baina, lehen erabakiaren ezinbestekotasuna mendratua gertatzen bada ere, aldi berean, eta hain zuzen ere prozesu horretaz beste xehetasunik eskaintzen ez duelako, elipsiak ezinbestekotasun horri neurri batean eutsi eta bigarren erabakiaren unera arte helarazten du: bigarren erabakiaren arrazoiak ia lehenarenak bezain ezinbestekoak izan zirelako ondorioa atera behar dugu irakurleok. Hau da, metonimia narratiboaren bidez, Atxagak, besteak beste, Davidek ETAn sartzeko oso arrazoi hertsakorrak izan zituela iradoki nahi izan du.

Ez hori bakarrik, ordea. Izan ere, bestaldetik Davidek ETAn ez sartzeko ere oso arrazoi hertsakorrak izan zituela ondoriozta baitaiteke kontakizunetik. Lehen erabakiarekin jarraituz, bada erabaki horrek berarekin dakarrena osoki ulertzeko funtsezkoa den elementu bat: Virginia. Berez, Joseba laguntza eske etorri baino dezente lehenago zeukan Davidek bere aukera eginda, Virginiarekin egotea, alegia $^{41}$. Hala, lehen erabakiaren unean honelaxe esaten dio Davidek Josebari: 'Honek guztiak ikara ematen zidak [...]. Gainera Virginiarekin egon nahi diat. Hik ezin duk ulertu'42. Hitzotan ikus daitekeenez, Davidek Josebaren eskaera onartuz gero Virginiarekiko harremana arriskuan jarriko duela sumatzen du. Josebak Daviden aurrean argudiatzen duenez une horretan Davidek Virginia gal lezakeenik zertan pentsaturik ez dagoen arren, kontakizunak ezkutatu duen lehen eta bigarren erabakien arteko uneren batean Davidi derrigor egokitu behar izan zaio ETAn sartu edo Virginiarekin geratu erabaki beharra ${ }^{43}$. Ezkutaturiko erabaki horretan, Davidentzat Virginiarekin geratzeko aukera erabakigarria izan behar izan da, kontakizunak Davidek Virginiari dion maitasuna biziki azpimarratzen baitu. Atxagak, beraz, Davidek ETAn ez sartzeko ere oso arrazoi hertsakorrak izan zituela iradoki nahi izan du.

Bada Daviden lehen erabakiaren azken ezaugarri bat ETAn sartzeko erabakiaren erabakiezintasuna azpimarratzen duena. Berez, Davidek Papiren taldeari laguntzerakoan ez zuen erabakirik hartu, egin behar zuena besterik ez baitzeukan egiterik: Derrida-ren hitzetan esateko, Davidek aldez aurretik ezarritako programa, erregela edo kalkulu bati jarraitu besterik ez zezakeen egin. Josebak aurkeztu zion programa Davidi, 'Iruainera joan beharra daukak, David. Bestela denak hilko ditiztek', jaulki zionean ${ }^{44}$. Programari zentzua ematen zion erregela aipatu beharrik ere ez zegoen: nork bere lagunei lagundu egin behar die ${ }^{45}$. Josebak berak egin zuen Daviden zalantza-izpi oro indargabetu zuen kalkulua: 'Ondo aterako duk eta hiri ez zaik ezer pasako. Behin gordelekuan sartzen dituanean, ni arduratuko nauk ${ }^{46}$. Osagarri hauekin guztiekin eraturiko makineriari bere burua errenditzea beste aukerarik ez zeukan Davidek, bere rola bete, automata baten modura. Davidek, beraz, ez zuen erabakirik hartu. Nork hartu zuen erabakia, orduan? Josebak? Hala pentsa daiteke eta hala da, hein handi batean, Joseba izan baitzen David makineria

41 - Ik. SS, 295-373. orr. passim.

42 - Ibid., 372. or.

43 - Josebak honela argudiatzen du Daviden aurrean: 'Ondo aterako duk eta hiri ez zaik ezer pasako. Behin gordelekuan sartzen dituanean, ni arduratuko nauk.' Hau da, itxura batean, behintzat, une horretan David eta Virginiaren arteko harremana ez dago arriskuan. Ik. SS, 372. or.

44 - SS, 371. or.

45 - Papiren taldekideetako bat Daviden unibertsitateko laguna zen, Agustin -Triku-, alegia. Ikus SS, 372. Or.

46 - Ibid. 
hartan inplikatu zuena. Baina Daviden kasurako jarraitu den arrazoibide berbera aplika dakioke Josebaren balizko erabakiari. Izan ere, Josebak makineria topatzerako ere abian zegoen jada beronen prozesua. David eta Josebaren arteko alde bakarra da Josebak makineria bere prozesuaren urrats aurreragoko batean topatu zuela. Hortik aurrera, ordea, Josebak ere ezin zuen makineriari bere burua errenditu besterik egin, bere rola automata baten modura bete, Davidengana jo, alegia. Beraz, Josebak ere ez zuen erabakirik hartu.

Hori eta horrenbestez, Daviden lehen 'erabakia' automatismoaren eremuan kokatzen da, Derrida-k dioen bezala erabakiak ez, baizik eta programa, erregela edota kalkuluen ondorio hutsak direnen eremuan, alegia. Gure hipotesian, bigarren 'erabakia', ordea, Derrida-ren ezinezko erabakien eremuan kokatzen da, erabakiezintasunaren eremuan, alegia. Hipotesiaren arabera, beraz, automatismoa ezin daiteke izan Atxagak bigarren 'erabakiaz' lehenaren nondik norakoetan utzi digun arrastoetako bat. Zein, orduan? Automatismoak eta erabakiezintasunak ezaugarri funtsezko bat partekatzen dute, subjektuaren erabakimenaren gainditzea, hain zuzen ere: automatismoan subjektuak ez du erabakitzen, programa, erregela edota kalkulu bat jarraitzen du; erabakiezintasunean subjektuak 'erabaki' egiten du, baina 'erabakia' ez dago subjektuaren baitan, 'erabakiaren' unea eroaldia baita. Subjektuaren erabakimenaren gainditze hori da, hain zuzen ere, Daviden lehen 'erabakitik' bigarrenera Atxagak helarazten duen ezaugarria metonimia narratiboaren bitartez. Labur esanda, Daviden lehen 'erabakiaren' automatismoaren bidez, Atxagak hauxe iradoki nahi izan du: Daviden ETAn sartzeko erabakiaren unea eroaldia izan zen.

Hortaz, Daviden lehen 'erabakiaren' nondik norakoek egiaztatu egiten dute ETAn sartzeko 'erabakia' erabakiezina izan zelako hipotesia. Erabakiezintasun hori da, azken batean, Atxagak adierazi eta azpimarratu nahi izan duena. Ondorioetara joz, nobelak une honetara arte eragindako galdera, agerturiko hutsune eta planteaturiko paradoxa orori harrera egokiagoa egin dakioke orain, behin Derridaren analisia kontuan hartuta, testua eta irakurlearen arteko distantzia estetikoa gainditu eta testuaren zehaztapen osoagoa lortuz. Hasteko, nobelak agertzen duen hutsunerik nagusienari, hau da, Davidek ETAn sartzeko izan zitzakeen arrazoien ingurukoari dagokionez, garrantzitsuena ez da arrazoi horiek zein izan ziren jakitea, erabakia bera erabakiezina izan zela ulertzea baizik. Davidek ETAn sartzea erabaki zuen unean ez zitekeen arrazoi, programa edota kalkulurik bat ere egon erabakia guztiz justifikatuko zuena. Une horretan, hutsune gaindiezina agertu zen Daviden erabakimenaren eta erabakiaren beraren artean: Derrida-ren hitzetan esateko, Daviden erabakiaren unea eroaldia izan zen. Davidek ez dauka, beraz, erabakia guztiz argitzerik, azaltzerik, justifikatzerik: Davidek, nolabait, ezin du bere erabakia kontatu. Horregatik ez da, hain zuzen ere, erabaki hori kontatzen Daviden memorialean, horregatik utzi du Atxagak erabakia elipsi batean murgilduta betiko. Irakurleak hutsunea betetzeko daukan modurik egokiena, beraz, hutsunea betetzerik zergatik ez dagoen ulertzea da.

Bestalde, erabakiezintasunak subjektuaren berezko barne-diferentziak azaleratzen ditu. Erabaki ezinezkoaren unean, subjektu arrazionalaren mugak ez dira gauza irrazionaltasunaren inbasioa geldiarazteko: arrazionaltasuna irrazionaltasun bihurtzen da, eta alderantziz. Jada ezin da, beraz, mugak non diren zehaztu: subjektua entitate zehatzezina bihurtzen da. Hau da, subjektuaren bezain berezkoa suertatzen da bere mugetatik barnealdera zein kanpoaldera dagoena: 
David aldi berean bera da eta beste(a) $\mathrm{da}^{47}$. Horrela, proiektu autobiografikoa ulertzeko ohiko modua ez da jada bideragarria, nork bere buruari nor den esateko asmoa ez baita guztiz betegarria. Honek ez du esan nahi autobiografia deitzen jarrai litekeen kontakizun-mota guztiz ezinezko bihurtzen dela: subjektuak esentziarik ez izateak ez dakar berekin subjektuaren erabateko ezabaketa; egia da ez dagoela modurik subjektua zer den argi eta garbi zedarritzeko, baina subjektuak existitzen jarraitzen du. Esaterako, Daviden memoriala autobiografia bikaintzat jo daiteke, oraindik ere. Goian erakutsi den lez, Soinujolearen semea-k bete-betean jarraitzen ditu genero autobiografikoaren arau eta ezaugarriak, generoaren adierazpen-indar osoa ustiatu eta proiektu autobiografikoaren dudarik gabeko balioa azpimarratuz. Alabaina, Soinujolearen semea-n genero autobiografikoaren adierazpen-indar osoa aktibatzearen helbururik behinena ez da generoa bere gauzapenik gorenera eramatea, generoak bere mugak eta ezintasunak azaleratzen dituen punturaino eramatea baizik: autobiografia -Davidek une batean dioen bezala- kontuak garbitzeko modua da, dudarik gabe, baina ez ditu kontu horiek inoiz guztiz garbituko $^{48}$. Horixe da nobelak puntu honetan irakurleari planteatzen dion distantzia estetikoa, subjektua eta proiektu autobiografikoa barne-diferentziez osaturik daudela ulertuta gainditu beharko litzatekeena.

Soinujolearen semea-k agertzen duen bikoiztasun narratiboaren arrazoia ere ia berez azaleratzen da argudiaketaren puntu honetaraino helduta. David aldi berean bera da eta beste(a) da: Daviden memorialak, beraz, berak eta beste(a)k batera idatzita egon beharko luke. Hau da, bikoiztasun narratiboa Daviden barnediferentziaren ondorio zuzena da. Bestalde, gorago argudiatu denez, Davidek ETAn sartzeko erabakia hartu zuela beharrean, hauxe esan beharko litzateke: ETAn sartzeko beste(a)ren erabakia Davidengan hartu zen. Azken gertakari hau ekarriko zuen prozesua Josebak abiarazi zuen. Beraz, metaforikoki behintzat, Josebarena da Davidengan hartu zen erabakia, Joseba da Daviden beste $(a)^{49}$. Horregatik txertatu du Atxagak Josebaren berridazketa egiturazko osagarri bezala, memorialak Davidek eta Daviden beste(a) $k$ batera idatzia behar zuelako eta Joseba zelako, hain zuzen ere, Daviden beste(a). Egiturazko osagarri honek, finean, Daviden barne-diferentzian du jatorria eta barne-diferentzia hauxe azpimarratzeko funtzioa $\mathrm{du}^{50}$.

Azken ohar bat atal honi amaiera jartzeko. Joseba Daviden beste(a) dela esateak ez dakar berekin Josebak eta Davidek elkar osatzen dutelako ideia, bestela esanda, Josebak eta Davidek ez diote elkarri eman bakoitzak 'gizabanako osoa' izateko falta zuena. Soinujolearen semea-k, kontrara, gizabanakoa eta osotasuna kontzeptu bateragaitzak direla iradoki nahi du. Beste(a)ren nozio dekonstruktiboa berezkoa

47 - Beherago xehetasun handiagoz azalduko den bezala, bitasun hauxe da arrazoi funtsezkoena nobelaren bikoiztasun narratiborako, hau da, Daviden memoriala Josebak berridatzita hel dakigun irakurleoi.

48 - Zentzu honetan, Robert Smith-ek dioenez, ezinezkoa da jada ongi mugaturiko autobiografia edota ongi itxitako subjektutasunei buruz hitz egin. Ik. Robert Smith, Derrida and Autobiography, 5. or. Bestalde,hortxe egon daiteke Atxagak Soinujolearen semea-n autobiografia hitza beharrean memoriala edota memoriak erabiltzearen arrazoia. Ik., hurrenez hurren, SS, 15. eta 21. orr

49 - Beste(a) diogunean ez dugu alter ego edo antzekorik adierazi nahi, subjektuaren mugetatik kanpo egonda ere subjektuari badagokiona baizik, beste $(a)$ ren nozio postestrukturalista edo dekonstruktiboa alegia. Zentzu honetan, Josebaren berridazketak ezartzen duen bikoiztasun narratiboa ez da ispilu-joko batena bezalakoa, non batak bestearen islan ezagutu ahal duen bere burua, non bata bestearekin identifikatu ahal den. Soinujolearen semea-ko bikoiztasun narratiboak, ordea, identifikazioak oro kolokan jartzen ditu, subjektuak ez baitauka jada bere burua identifikatzerik ezein irudi zehatzetan ere.

50 - Josebaren berridazketa osagarri funtsezkoa da nobelaren egitura eta irakurlearen harrerarako, berridazketaren arrastorik gabe zaila bailitzateke Daviden nortasunak memorialean zehar duen presentzia eskergan pitzadurarik batere sumatzea. 
zaio gizabanakoari beti, gizabanakoen artean egon daitezkeen kidetasunetatik haratago: gizabanakoak ez du inoiz ere bere beste(a) erabat azpiratzerik, errenditzerik, bereganatzerik izango. Hala egiazta daiteke nobelan ere, ia amaieran dagoen David eta Josebaren arteko elkarrizketa batean, behin Daviden eta Josebaren ahaleginak kontuak garbitzeko bukatutzat jo daitezkeenean. Honelaxe dio Josebak:

Niri ere asko kostatzen zaidak ulertzea [...]. Baina ez Mamousinetik atera eta gero egin nuena, baizik eta Guzziarekin hire bila joan nintzen egunekoa. Zergatik sartu nintzen zulo horretan. Zergatik atera hindudan hi Virginiaren ohetik zulo berera bultzatzeko. Horregatik idatzi behar diat liburua ${ }^{51}$.

Josebak aipatzen duen liburuaren amaieran -memorialaren berridazketaren amaieran, alegia- agertzen da adierazpen hau. Amaiera helduta, ahalegin guztiak eginda ere, Josebak -Davidek bezala- ezin du bere burua ulertu, ez guztiz behintzat. Davidek eta Josebak ezingo dute inoiz guztiz justifikatu zergatik sartu ziren ETAn; Davidek eta Josebak ezingo dute inoiz nor diren guztiz azaldu; Davidek eta Josebak ez dute inoiz nork bere beste(a) guztiz errenditzerik izango.

\section{Nazioa traizionatu nazioari leial izateko: nazioaren muga zehatzezinak.}

Batzuetan, identitate kultural, identitate nazional edota identitate linguistikoen aldeko borrokak ekimen zintzoak dira. Baina, aldi berean, euren identitatearen alde borrokan ari direnek kontuan hartu behar dute identitatea ez dela gauza baten berberatasuna, edalontzi hau, kasu, mikrofono hau, baizik eta identitatearen baitako diferentzia bat barne hartzen duela.

Jacques Derrida, The Villanova Roundtable

Erakutsi bezala, Soinujolearen semea-ren lehen bi herenek bikoiztasun bat hartzen dute oinarri estruktural eta helburu narratibotzat, David eta bere beste(a)ren arteko bikoiztasun moduko hori alegia, ETAn sartzeko erabakian azaleratua eta David eta Josebaren arteko bikoiztasun narratiboan metaforikoki islatua. Daviden bikoiztasuna ETAn sartzeko erabakiaren unean azaleratzeak Soinujolearen semea-ren gairik beharbada nagusienak seinalatzen ditu, hots, gizabanakoak duen komunitatea edo nazioarekiko erantzukizuna, komunitatea edo nazioaren zerizana, eta, bistan da, Euskal Herriko gatazka politikoa. Gai hauek garatuz eta David eta Josebaren historiaren ifrentzua eskainiz, nobelaren azken herenak ETAn sartzeko erabakiaren kontrapuntu simetrikoa hartzen du hizpide, hau da, David eta Josebak ETA uzteko harturiko erabakia. Hemen ere, kontakizunak bikoiztasun edo dobletasun bat du ardatz, toles bat, tolestura bat, traizio bat alegia, 
kasu honetan Josebak buruturiko traizioa eta Josebarengan islaturiko dobletasuna, Josebaren dobletasuna, Joseba eta bere alter ego organizatuaren artekoa, Joseba vs. Etxeberria, alegia.

Josebak ez zion inoiz bere traizioaren berri inori eman Hiru aitorpen izeneko testua jendaurrean irakurri arte. Stoneham-en bisitan zegoen bitartean literaturzaleelkarte batek antolaturiko irakurketa publikoan testua ezagutzera eman arte, Davidek berak ere ez zekien deus askorik Josebak hogeita hiru urte lehenago egindakoaz. Bere aitorpenean -Etxeberriaren aitorpena izenekoan, alegia- Josebak zuzen-zuzenean jotzen du harira. ETAn sarturik hainbat denbora eman ondoren, inbertsio bat gertatu zen beragan eta militantziarekin zerikusia zuen guztia arbuiatzen hasi zen: organizazioaren agiriak, lexikoa, diskurtsoa, atentatuak ${ }^{52} \ldots$ 1976. urtea zen, ETAren barruan bide militarra eta bide politikoaren defendatzaileen arteko liskarrak hasiak zirenean jada. Militaristek zioten jarrera moderatuaren aldeko guztiak saldukerian ari zirela, traizioan alegia, eta ez zutela halako irtenbiderik onartuko. Josebarentzat, ordea, ETA uztea inork kendu ezin zion eskubidea zen. Hala, bere burua poliziari ematea deliberatu zuen, organizazioari traizio egitea, alegia ${ }^{53}$. Bere bi komando-kideentzat ere -Agustin/Triku eta David/Ramuntxo, alegia- irtenbiderik onena ETA uztea zela erabakita, Josebak hauei ezer esan gabe hiruron atxiloketa prestatu zuen poliziari abisua emanda. Triku hiltzear egon zen atxiloketaren ondorengo tortura-saioetan. Atxiloketa gertatzerako, Davidek ere bere burua bere aldetik entregatuz ETA uztea erabakita zeukan. Hala, ezusteko atxiloketa aprobetxatuta, bere kontrako akusazio guztiak onartu eta poliziari Iruaingo gordelekuaren berri eman zion $^{54}$. Hau dela eta, organizazioak erorketaren errudun eta traidoretzat jo zuen David, ostrazismoan eta heriotza-mehatxupean bizitzera kondenatuz Stoneham-era alde egin zuen arte ${ }^{55}$. Josebari dagokionez, laster sumatu zuen poliziak atxilotu ondoren ematen zion tratu adeitsuaren bidez traidorea nor izan zen argitu egin nahi ziola organizazioari. Azken honek egia behin jakinda jarri ziezaiokeen zigorraren beldur, Josebak bere burua nahita zauritu zuen ziegan. Honela, traizioaren akusazioa ekidin zuen, susmoak Davidenganantz bideratu zirelarik. Finean, atxiloketatik hamalau hilabetera eta Josebak gutxi gorabehera aurreikusi bezala, kalean zeuden hirurak amnistiarekin, organizaziotik kanpo eta bizimodu berri bati ekiteko aukerarekin.

Daviden memorialarekin egin bezala, Josebaren aitorpenaren laburpen hau beharrezkoa zen ondoko argudiaketari testuinguru egokia emateko. Hasteko, Josebaren traizioari buruz hitz egin beharrean, Josebaren traizioei buruz hitz egin behar dela azpimarratu behar da. Izan ere, bi traizio zeharo ezberdin aipatzen dira Josebaren aitorpenean. Alde batetik, ETAko militaristek beren tesien arabera

52 - SS, 446. or.

53 - ETAko militaristen jarrerari aurre eginez, Josebak uste osoz -ia harrotasunez, esan liteke- hartu zuen beretzat haiek banatzen hasitako traidore-estigma: 'Esan ohi den bezala, nire gelako bakardadean jardun nuen gogoetan, erretorikarik gabe, mikaztasunez, umekeriarik gabe, eta erabakia hartu nuen: neure burua entregatuko nion poliziari. Edo, gordinago adierazita -erretorikarik gabe etab.-, traizioa egingo nion organizazioari.' Ik. SS, 447. or.; letra etzana neuk jarria da. Traidore-estigmaren aldarrikapen moduko honetan, Josebarentzat ETA uztea inork kendu ezin zion eskubidea zela atzeman daiteke. Hau da, militaristen traizio-erretorika zitala gorabehera, Josebak uste osoz utzi nahi zuen organizazioa, eta hala egitea traiziotzat jotzen bazen, bera traidore bihurtuko zen. Gauzak horrela, bistan da Josebarentzat ETA uztea ez zela benetako traizioa.

54 - Josebarengan bezala, Davidengan ere inbertsio bat gauzatu zen atxiloketa baino lehen. David damu zen gertaerek harturiko norabideaz, Iruaingo gordelekuaren funtzioa pertsegituak salbatzetik bahitutako jendea ezkutatzera pasatu izanaz, kasu (ik. SS, 443. or.). Horregatik eman zion poliziari gordelekuaren berri.

55 - SS, 445. eta 449-50. orr. 
traiziotzat jotzen zutena daukagu: tesi horien arabera, ETA uztea, hots, borroka armatuari ez eustea kontra-iraultzan erortzea zen eta, ondorioz, ETA uztea ETAri traizio egiteaz gain, nazioari, Euskal Herriari ere traizio egitea zen ${ }^{56}$. Josebak, ordea, ez du onartzen ETA uztea traizioa denik, arestian erakutsi bezala. Ez da 'traizio' hori Josebaren aitorpena eragin duena. Bestaldetik, berriz, Josebak traidoretzat jo izan du bere burua poliziarekin tratua egin eta bere aitorpena irakurri bitarteko urte luzeetan. Izan ere, Josebak traizio egin zuen, baina berak traiziotzat onartzen duen bakarra bere lagunei eginikoa da, Trikuri eta Davidi, alegia, eta hauei zuzendu zaie, Davidi bereziki, aitorpena egiterakoan ${ }^{57}$. Izan ere, Josebaren jokaerak ondorio latzak ekarri zizkien biei: tortura erdiragarriak Trikuri eta denbora luzean traidorearen estigma eraman beharra Davidi ${ }^{58}$.

Atxagak, beraz, hasiera batean ETAri eta nazioari eginiko traizioa zena -ETAren arabera, behintzat- lagunei eginiko traizioa bihurtu du, komunitatea edo nazioaren eremuan kokaturiko arazoa gizabanakoen arteko harremanen eremura eramanez. Halere, horrek ez du esan nahi Atxagak modu horretan lehen traizioaren gaia eta Euskal Herriko gatazka politikoarena jorratzeari muzin egin dionik. Izan ere, ez da ahaztu behar Soinujolearen semea-ren gairik nagusienen artean gizabanakoak duen komunitatea edo nazioarekiko erantzukizuna, komunitatea edo nazioaren zerizana eta Euskal Herriko gatazka politikoa daudela, arestian aipatu bezala. Horrela, Josebak Triku eta Davidi eginiko traizioaren istorioak ez du zentzu narratiborik ezpada ETAri eta nazioari eginiko balizko traizioaren testuinguruaren baitan. Hau da, ETA uztea traiziotzat jo behar ez dela iradoki ondoren ere, Atxagak 'traizio' horren gaiari eutsi nahi izan dio, halako moldez, non Josebak bere lagunei eginiko traizioaren istorioak, zeharka bada ere, ETAri eta nazioari eginiko balizko traizioaren gaineko istorioa izaten jarraitzen duen. Azken batean, hemen ere, Daviden erabakien kasuan bezala, metonimia narratibo bat aurkitzen dugu: Josebaren lehen traizioaz, hots, gizabanakoak nazioari eginiko traizioaz hitz egiteko, Atxagak beste traizio bat asmatu du, Josebak bere lagunei egindakoa, alegia ${ }^{59}$.

Josebak bere lagunei egindako traiziora jo behar dugu, beraz, aurrera egitekotan. Triku eta Davidi bere asmoa ezkutatu bazien ere, Josebak hiruron hobe beharrez prestatu zuen guztion atxiloketa, hirurok ETAko militantziarekin gogogabetuta zeudela ikusita eta guztiok urte askotako kartzelaldi seguru samar batetik salbatzearren $^{60}$. Egia da erabaki horrek sufrimendu lazgarriak ekarri zizkiela bai Trikuri, bai Davidi, Josebari berari baino askozaz lazgarriagoak gainera. Alabaina, zenbait urteren buruan, traizioak bere onura erakutsi zuen, ETA garaiz utzi izanari esker, militantziakoa baino askozaz hobeto zegokien bizimodua aurkitu baitzuten guztiek $^{61}$. 'Traizio' hau, beraz, kaltegarria ez ezik, onuragarria ere izan zen

56 - Atxagak militaristak deitzen dituenak, bistan da, garai hartan ETAren barruan sorturiko zatiketaren ondorioz ETA militarra edo ETA(m) osatu zutenak dira. SS, 447. or.

57 - SS, 453. Or.

58 - SS, 451-3. orr. Oroz gain, erorketaren eragilea bera izan zela organizazioari aitortu ez izanak egiten du Josebaren jokaera zinez deitoragarria irakurlearen begien bistara, hala jokatuz David kinka larrian uzten zuela jakinda gainera.

59 - Daviden erabakien artean eta Josebaren traizioen artean Atxagak ezarritako metonimia narratibo hauen arteko alde bakarra hauxe da: erabakien kasuan, efektua kontatu ordez -ETAn sartzeko erabakiakausa kontatu du Atxagak -Papiren taldeari laguntzeko erabakia-; traizioen kasuan, berriz, kausa xehatu ordez -ETAri eta nazioari eginiko traizioa- efektua xehatu du Atxagak -Triku eta Davidi eginiko traizioa-. 60 - SS, 447-8. orr.

61 - Josebak honelaxe laburbiltzen du Trikuk eta Davidek -Ramuntxok- aurkitu duten bizimodu berria: 'Triku berpiztu egin zen Montevideon, eta indiano aberats bihurturik dago orain, hiriko jatetxerik onenetakoaren jabe. Eta Ramuntxo, berdin, edo hobeto. Bere kasuan, maitasunak erreskatatu zuen infernutik.' Ik. SS, 453. or. 
traizionatuentzat. Hala, Josebaren ekintza ezin da traiziotzat bakarrik hartu, traizioaren kontrakotzat, hots, zaintzatzat edo leialtasuntzat ere hartu behar da. 'Traizioa', beraz, hala deitzen jarraitu nahi bada ere, aukera egokitzat, are aukerarik egokientzat ere jo daiteke une jakin batean. Hauxe da Atxagak istorio honen bidez egin nahi izan duen iradokizuna ${ }^{62}$. Ez hori bakarrik, ordea, goian aipatu metonimia narratiboa gogoan hartuta, iradokizun honek benetako hizpide Josebak ETAri eta nazioari eginiko 'traizioa' duela ondorioztatu behar baita. Hau da, Atxagaren azken buruko iradokizuna honen antzeko baieztapen batera bil daiteke: ETAri eta nazioari 'traizio' eginez borroka armatua espainiar trantsizioaren garaian bertan behera uztea aukera onuragarria zen, baita Euskal Herriarentzat ere; are gehiago, 'traizio' hori aukera egoki eta zentzuzkoentzat jo zitekeen, baita Euskal Herriari leial izateko modurik hoberentzat ere.

Puntu honetan, funtsezkoa da ohartzea Atxagak iradokizun hori egitean ez duela guztiz alboratu nahi izan ETA uztea traizioa zelako ideia. Argi dago Atxagak guztiz bestelako zentzu batekin bereganatu duela ETAko militaristek jaulkiriko salaketa. Hauentzat ETA uztea traizio hutsa zen, traizio garbia, traizio betea, kalterik baino ez zekarren ekintza; Atxagarentzat, ordea, ETA uztea ekintza onuragarria zen. Zentzu horretan, Atxagak ukatu egiten du ETAko militaristen ustea, honen adierazgarria nobelan Josebak harturiko jarrera delarik. Alabaina, azken buruan ETA uzteari buruzkoa den beste traizio-istorio bat asmatuz, Atxagak eutsi egin dio nolabait ETA uztea traizioa zelako ideiari. Egia da, esan bezala, Atxagak bereganatu eta gero traizioaren ideia guztiz eraldatuta agertzen zaigula, berak aurkezten digun traizioa finean onuragarria suertatzen baita. Baina, aldi berean, traizioa hor dago, traizioaren kaltegarritasuna hor dago, bai Josebak Triku eta Davidi eginiko traizioaren istorioan, baita -metonimia narratiboa dela medio eta oroz gain- ETA uztearen ekintzan ere. Atxagak, dirudienez, intentzio osoz nahastu ditu nazioari leial izatea eta nazioa traizionatzearen kontzeptuak, traizioa eta leialtasunaren arteko mugak zehatzezinak direla iradokiz. Berariazko anbiguotasun hau ez da batere ohikoa eguneroko politikaren jokoan, non, hain zuzen ere, anbiguotasunetik izurritetik bezala ihes egiten den koherentzia eta sinesgarritasun politikoak lortzeko modu bakarra bailitzan, nahiz eta, askotan, ihesaldi horrek ez duen berekin ekartzen dogmatismoa eta monolitismoa baino. Gauzak horrela, eta adiera bakarreko diskurtso politikoen jokoa gaindituz, Soinujolearen semea ETA espainiar trantsizioaren garaian desagertu behar zelako aldarrikapen politiko hutsetik haratago doa, Atxagak, bistan da, aldarrikapen hori ere egin nahi izan duen arren. Azken batean, Atxagak nazioarekiko leialtasuna ulertzeko ohikoa ez bezalako modua iradoki nahi izan du. Are garrantzitsuago, Atxagak nazioaren izaera ulertzeko ohikoa ez bezalako modua iradoki nahi izan du, ondoren argudiatuko den bezala.

XVIII. mendean garatu, indartu eta unibertsal bihurtzeko bidean jarri zenetik, nazioaren kontzeptu modernoa hainbat aldaera teorikotan gauzatuz joan da, zeintzuek, batzuetan, ñabardura esanguratsuak proposatu dituzten esentzialismomailari dagokionez ${ }^{63}$. Hala, funtsean, bi mutur teoriko atzeman daitezke nazio-

62 - Baieztapen honen frogagarria Atxagaren beraren hitzotan aurki daiteke, Buenos Aires-eko Página/12 egunkariak argitaraturiko elkarrizketa batetik hartuak: 'Aquí [Soinujolearen semea-n, alegia] se encuentra a una persona que cree que la traición no sólo es una forma de salvarse, sino que además es una forma de ser racional, inteligente, de optar por lo mejor en ese momento.' Ik. Ángel Berlanga, 'Reflexiones sobre el "no matarás". Entrevista con el escritor vasco Bernardo Atxaga', Página/12 (2005-07-06) <http:// www.pagina12.com.ar/diario/cultura/index-2005-07-06.html> [2006ko ekainaren 8an azkenekoz atzitua] 63 - Ezaguna denez, nazioaren kontzeptu modernoak XVIII. mendeko pentsabidean du jatorria, pentsalari alemaniar erromantiko hainbaten lanean, batez ere. Erromantizismo alemaniarraren nazio- 
kontzeptuaren historian zehar ${ }^{64}$. Batetik, nazioaren funtsa irizpide etnikoetan oinarritu duen ikuspegia dugu, zeinaren arabera nazioa jatorri, hizkuntza eta ohitura-multzo bereko komunitatea den eta nazionalitatea jaiotzetik erabakia dagoen. Bestetik, nazioaren funtsa irizpide hiritarretan oinarritu duen ikuspegia dugu, zeinaren arabera nolabaiteko burujabetza politiko komuna helburu duen edozein giza taldek nazioa osatzen duen eta nazionalitatea gizabanakoaren borondatean datzan. Bi mutur teoriko hauen arteko diferentziak ez dira hutsalak, eman berri diren definizioetan suma daitekeen bezala. Diferentziak gorabehera, bada osagarri komun bat kontzepzio hauei guztiei ezinbestekoa zaiena, tradizioa, alegia: ez dago nazioa irudikatzerik ezaugarri kultural jakin batzuen belaunaldiz belaunaldiko transmisiorik gabe. Oroz gain, nazioa tradizioa da, Ernest Renan filosofo eta idazle frantziarraren hitzotan ikus daitekeen bezala:

Nazioa arima bat da, izpirituzko oinarri bat. Bi gauzek, bat eginda azken batean, osatzen dute arima edo oinarrizko izpiritu hau. Bata iraganean dago, bestea orainean. Bata elkarren artean oroimen-sorta aberatsa edukitzean datza; bestea gaurko baimenean, elkarrekin bizitzeko nahian, zatitu gabe jaso den ondarea iraunarazteko borondatean oinarritzen $\mathrm{da}^{65}$.

Renan-entzat, beraz, nazioa tradizioa da. Ez edonolako tradizioa, alabaina, zatitu gabe transmititzen den tradizioa baizik. Nabardura hau funtsezkoa da, nazioa gorpuzten duen tradizioan azken buruan zatiezina den erdigune bat kokatzen baitu, nazioari bere berezkotasuna ematen dion muin aldaezin eta iraunkor bat, esentzia bat, alegia. Hala, esentzia horrek irizpide garbia ematen du tradizioa eta traizioa zehazki ezberdintzeko: nazioaren esentziari onuragarri zaion jokabide oro tradizioa litzateke; esentziari kaltegarri zaion jokabide oro, ordea, traizioa. Renan-en nazioikuskeratik eratortzen den ondorio hau, beraz, ez dator bat Atxagaren iradokizunarekin, hots, tradizioa eta traizioaren artean zehazki ezberdintzerik ez dagoelako ideiarekin ${ }^{66}$. Kontua da ideia honen atzean Atxagaren nazio-ikuskera dagoela, Renan-ena ez bezalako nazio-ikuskera antiesentzialista, alegia, ondoren erakutsiko den bezala.

Hasteko, tradizioa eta traizioaren artean zehazki ezberdintzerik ez dagoelako ideiaren arabera, bietako zein lehenetsi erabakitzerakoan nazioa irtenbiderik gabeko sorgin-gurpil batean sartuko litzateke. Izan ere, kaltegarria zaion neurrian traizioa arbuiatu eta tradizioaren onura lehenetsiko balu, nazioak bere buruari kalte ere egingo lioke, traizioak ekar liezaiokeen onuraz gabeturik geratuko bailitzateke; beraz, nazioak tradizioaren kaltea arbuiatu eta traizioa lehenetsi beharko luke. Baina onuragarria zaion neurrian traizioa lehenetsi eta tradizioaren kaltea arbuiatuko balu,

ikuskera herri espirituaren ideian laburbil daiteke -Volksgeist delakoan, alegia-, bere patuaren jabea den herri baten helburu-komuntasuntzat ulertu ohi dena. Ik. José Ferrater Mora, Diccionario de filosofía, 6. arg., 4 ale (Madril: Alianza, 1979), II, 1014-5. orr.

64 - Nazio-kontzeptuaren historiaren gaineko zertzelada hauetarako honako erreferentzia hau erabili da: Miscevic, Nenad, 'Nationalism', in Edward N. Zalta (ed.), The Stanford Encyclopedia of Philosophy (2005eko neguko edizioa) <http://plato.stanford.edu/archives/win2005/entries/nationalism> [2006ko ekainaren 19 an azkenekoz atzitua]

65 - Ernest Renan, Zer da nazioa?, itzul. Esteban Antxustegi (1882ko hitzaldia; Bilbo: Euskal Herriko Unibertsitatea, 2004), 129. or.

66 - Atxagaren iradokizuna adieraztean, leialtasuna eta traizioa aipatu dira arestian. Bestalde, Renan-en definizioak zabalduriko testuinguruan leialtasuna eta tradizioa sinonimotzat har daitezke, bistan da. Beraz, Atxagak Soinujolearen semea-n egin iradokizuna beste modu honetan adieraz daiteke: tradizioa eta traizioaren arteko mugak zehatzezinak dira. 
nazioak berdin-berdin egingo lioke kalte bere buruari, traizioak ekarriko liokeen kalteari ateak irekiko bailizkioke; beraz, nazioak traizioaren kaltea arbuiatu eta tradizioa lehenetsi beharko luke. Ondorioz, ez dago erabakitzerik non jarri behar diren nazioa babestu eta determinatu behar duten mugak: nazioak berezko duenak, bere mugen barrualdeari dagokionak, onuragarria zaion tradizioak alegia, mugetatik kanpo egon beharko luke, kaltegarria ere bazaio-eta; nazioari berezko ez zaionak, bere mugen kanpoaldeari dagokionak, kaltegarria zaion traizioak alegia, mugetatik barne egon beharko luke, onuragarria ere bazaio-eta. Hitz batean, nazioa determinatzen duten mugak zehatzezinak dira, erabakiezinak. Nazioa ez da bera bakarrik, beste (a) ere bada. Nazioa ez dagokio berberatasunari, barne-diferentziari baizik. Nazioaren izaera ez da esentziala, diferentziala baizik. Nazioaren izaera diferentzial hauxe da, hain zuzen ere, traizioa eta tradizioaren edo leialtasunaren artean argiro ezberdintzea galarazten duena. Izaera horixe da, beraz, Josebaren traizioaren istorioari zentzua ematen diona eta Atxagak istorio horren bidez azpimarratu nahi izan duena ${ }^{67}$.

Kulturaren kontzeptua bere adiera zabalean hartuta, hau da, kultura giza talde, nazio edota zibilizazio baten mundu-ikuskera eta jokamoldeen multzotzat hartuta, Soinujolearen semea-k, Atxagaren nazio-ikuskera antiesentzialistaren adierazgarria den heinean, berebiziko garrantzia erdiesten du euskal kulturarentzat, ez gertakari literario bezala soilik, ezpada gertakari kultural bezala ere. Izan ere, Mendebaldeko gainontzeko herrietan bezala, nazioaren ideia euskal kultura edo munduikuskeraren hatsarre funtsezkoenetakoa da. Egun, Mendebalde osoan bezala gurean nagusi den nazio-ikuskerak oinarri esentzialista garbia dauka. Nazio-ikuskera horren arabera, herri bakoitza esentzia-multzo baten jabea den heinean entitate bakar,

67 - Azken paragrafo honen helburua ez zen artean Atxagaren nazio-ikuskera antiesentzialistaren aldeko argudiaketa filosofikoa egitea, hau da, nazioak esentziarik ez duela argudiatzea. Asmoa, hasteko, nazioikuskera hori aurkeztea eta azpimarratzea zen, bai Josebaren istorioaren sorburu filosofiko bezala, bai istorio horren helburu narratibo bezala, hau da, Atxagak azken buruan adierazi nahi izan duen ideia bezala. Paragrafoak, bistan da, nazioak esentziarik ez duelako ondorioa (B) tradizioa eta traizioaren arteko mugak zehatzezinak direlako premisan (A) logikoki inplikatuta dagoela baino ez du erakusten: $\mathrm{A} \rightarrow \mathrm{B}$. A premisa egiazkoa dela frogatu gabe dagoenez, paragrafoak ez du balio B proposizioa egiazkoa dela frogatzeko. Asmoa hori izan balitz, argudiaketa zirkular baten falazian harrapatuak izango ginen, A$\mathrm{k}$ B inplikatzen duenez, frogatu nahi genuen ondorioa hasieratik premisaren tokian izango genuen-eta. Bestalde, eta esandakoaren ondorioz, nazioak esentziarik ez duela frogatzeko nahikoa izan liteke tradizioa eta traizioaren arteko mugak zehatzezinak direla frogatzea. Azken hauxe da Jack M. Balkin egiten saiatu dena konstituzio-zuzenbidean tradizioaren kontzeptuak jokatzen duen rolaren gaineko artikulu batean. Ik. Jack M. Balkin, 'Tradition, Betrayal, and the Politics of Deconstruction', Cardozo Law Review 11 (1990), lineako bertsioa, 1-18. or. < http://www.yale.edu/lawweb/ jbalkin/articles/tradit1.pdf> [2006ko ekainaren 21ean azkenekoz atzitua]. Hasteko, tradizioaren kontzeptua bi aurreiritzi metafisiko nagusiri loturik ulertu ohi dela ohartarazten du Balkin-ek, batetik, tradizioa zatiezina dela -gogoratu Renan-, eta bestetik, tradizioak dioena zuzena dela (4. or.). Ildo honi jarraiki, Balkin-ek tradizioaren gaineko bi aurreiritziok gezurtatzen dituzten adibideak eskaintzen ditu, AEBetako historiatik harturiko adibideak, hain zuzen: batetik, estatua eta elizaren arteko banaketaren printzipioa, adibidez, otoitz egun nazionaletarako presidenteak eginiko deialdiekin, AEBetako kongresuko kapilautza ofizialekin edota Eguberri-arbola nazionalekin batera existitu izan da, halako moldez, non, bistan da, tradizioa ez da osotasun kohesionatua bezala existitzen, printzipio eta kontraprintzipioez osaturiko multzo nahasia bezala baizik (6. or.); bestetik, AEBetan arraza-segregazioak tradizio bezala hain luze iraun izanak, adibidez, tradizioa askotan ez dela zuzena frogatzen du (6-7. orr.). Ondoren, tradizioaren analisi dekonstruktibo bati ekiten dio Baltin-ek. Hasteko, 'tradizio' hitzaren etimologiara jotzen du, harrigarri samarra suertatzen den datu linguistiko bat eskaintzeko: 'tradizio' hitz modernoa, traditio latindarretik dator; baita 'traizio' hitz modernoa ere, ordea! Hau da, 'tradizio' zein 'traizio' hitzek esanahi berbera dute jatorrian, tradere aditz latindarrarena, alegia: eman, eskura eman, entregatu (7. or.). Datu honek tradizioa eta traizioa elkarrengandik hain urruti ez daudela sumarazten digu jada. Ondoren, Baltin-ek tradizioa, berez, traiziotzat har daitekeela seinalatzen du eta nola: batetik, tradizioa errespetatzeak etorkizunean gauza litezkeen beste alternatiba batzuk alboratzea dakar berekin, hau da, tradizioa estradizioa da beti; bestetik, tradizio bat errespetatzea beronekin lehian dauden gainerako tradizioak traizionatzea da, hau $\mathrm{da}$, pentsabide jakin baten hegemoniaren alde egitea (8. or.). Honen guztiaren ifrentzuan, bistan da, 
ezberdin eta burujabea da. Bestalde, gainerako izaki edo entitateena bezala nazioaren lehenbiziko egitasmoa irautea da, hots, nazioa den horri eustea, bere bakartasun, ezberdintasun eta burujabetasuna defenditzea, alegia. Horrenbestez, nazioak mugak behar ditu, nolabaiteko mugarik ezean ez baitago modurik bermatzeko arrotzak nazioa kutsatu, desitxuratu edo are ezabatu ere egingo ez duela. Gauzak horrela, Mendebalde osoan nagusi den nazio-ikuskeraren arabera mugek ahalik eta garbien egon behar dute zedarriturik, mugak zenbat eta garbiagoak, nazioa orduan eta sendoagoa izango baita. Honen guztiaren aurrean, Atxagarena bezalako ikuskera antiesentzialistek aldarrikatzen dutena ez da, zoritxarrez gehienetan ulertzen den bezala, nazioaren ezabaketa, ezta nazioak irauteko behar dituen mugen ezabaketa ere. Ikuskera hauek, funtsean, nazioa determinatzen duten mugak zehatzezinak direla diote. Hau da, nazioak nolabaiteko mugak behar dituela onartzeaz batera, muga horiek non jarri erabakiezina dela aldarrikatzen da. Bestela esanda, nazioak berezkoa du arrotzarekiko irekidura nolabaitekoa, are beharrezkoa ere, halako moldez, non nazioa zer den eta arrotza zer den guztiz ezberdintzea ezinezko bihurtzen den.

Ikuskera antiesentzialistok aintzat hartzeak Mendebaldeko nazio-kultura goitik behera birdefinitzea ekarriko luke, euskal nazio-kultura barne. Kultura berriak zertara eramango gintuzkeen argiro erakustea, ordea, zaila ez ezik, ezinezkoa ere bada, nazioa zer den ezin determinatzeak nazio-eredu zehatzik gabe uzten baitu egitasmo nazionalista, helburu edo telos konkreturik gabe alegia, nazioaren aldeko lana unean uneko analisi eta erabakietan bakarrik gauza litekeen praktika politiko amaigabea bihurtuko litzatekeelarik. Soinujolearen semea-ri dagokionez ere, kultura berriaren ondoriozko nazio-eredu zehatzak arakatu baino Atxagak nazioaren zehatzezintasunaren ideia azpimarratu nahiago izan duela esan daiteke. Ondorioak beharrean ideia bera azpimarratzea ulertzekoa da oso, nazio-ikuskera esentzialistak gurean egun duen nagusitasun erabatekoaren aurrean zaila baita alternatibarik badagoela iradokitzetik haratago joatea. Zentzu horretan, nazioaren zehatzezintasunaren ideia are gehiago indartzea izan daiteke iruzkin honek, puntu honetara iritsita, har dezakeen biderik egokiena. Horretarako, Atxagaren munduikuskerarekin antzekotasun handia duen Jacques Derrida-ren pentsabidera joko dugu berriro, azken honen zehaztasun eta sendotasun analitikoak Atxagaren ideien bozgorailu bezala baliatzeko asmoz.

traizioa ere tradiziotzat har daitekeelako ideia dago, traizio oro tradizio berri baten hasiera den heinean (10. or.). Amaitzeko, Baltin-ek honela burutzen du bere analisi dekonstruktiboa: 'Tradizioa hazi eta garatu ahala bere burua aldatuz doa. Eta bere burua aldatu ahala, aldi berean leiala eta desleiala da bere buruarekin. Lehenago zegoenaren transmisioa da; baita aldaketa ere, txikia edo sotila izan arren. Berberatasunaren eta diferentziaren aldi bereko sorketa da. Tradizioa da; traizioa da, biak batera.' (10. or.; itzulpena neurea da). Baltin-en argudiaketa nahikoa arrazoi eskaintzen digu tradizioa eta traizioaren mugak zehatzezinak direla baieztatzeko. Halere, esentzialistek, tradizioan erdigune aldaezin eta iraunkor bat ikusi nahi dutenek, badute oraindik ere zirrikitu bat beren ikuskerari eutsi ahal izateko. Izan ere, esentziaren ideia ez da guztiz bateraezina Baltin-ek deskribatzen duen tradizioaren denboran zeharreko garapenarekin. Garapen hori, hain zuzen ere, tradizioaren esentzia azaleratzea ekarriko lukeen prozesu bezala ikus liteke, tradizioari hutsal, eragozgarri edo kaltegarri zaiona, hots, tradizioari akzidental zaion guztia pixkanaka arbuiatuz, azkenerako tradizioari esentzial zaiona bakarrik atzematea eta finkatzea lortuko lukeen prozesu bezala, alegia. Hitz batean, tradizioak esentzia bat duelako ideiak pentsabide modernoaren giltzarri den aurrerabidearen kontzeptu teleologikoan dauka euskarria, historia eta aurrerabideak telos bat, helburu eta helmuga bat dutelako kontzeptuan alegia, non entitate bakoitzak bere esentzia aurki dezakeen. Edonola ere, hemen Atxagaren nazio-ikuskeraren alde egingo da, nazioak esentziarik ez daukala argudiatuz. Horretarako, esentzialistak euskarri oroz gabetzen dituen Jacques Derrida-ren argudiaketa batera joko da hurrengo orrialdeetan, nazioak arrotzarekin abegikor izateko duen betebeharretik abiatzen den argudiaketa batera, hain zuzen ere. 
Derrida-ren nazio-ikuskeraren giltzarrietako bat abegikortasunaren nozioa $\mathrm{da}^{68}$ Bai gizabanakoak, bai nazioak arrotzari harrera on edota ostatu eskaintzea betebeharra dutela abiapuntutzat hartuz, Derrida-k abegikortasunaren barnelogikan bertan aurki daitekeen bideraezintasuna azaleratzen du. Hasteko, abegikor izatea, berez, arrotzari ostatu ematen zaion tokiaren jabearen esku dago soilik, ostalariaren esku, alegia: abegikortasuna ez datza arrotzari besteren jabetzan ostatu eskaintzean, nork bere jabetzan ostatu eskaintzean baizik. Hau da, abegikortasuna ostalariaren jabegotik eratortzen den aukera da. Honezaz gain, ostalariak bere jabegoari eutsiko diolako baldintzapean eman behar dio ostatu arrotzari: hala gertatuko ez balitz, hots, ostalariak bere jabegoari eutsiko ez balio, arrotzari eskainitakoa abegikortasuna bainoago kapitulazioa izango litzateke. Beraz, abegikortasuna nork bere jabetzari eusten dion bitartean arrotzari ostatu ematean datza $^{69}$. Bestalde, abegikortasunak bilatu behar duen azken helburua arrotza etxean bezala sentiaraztea da, bestela arrotzari eskainitakoa abegi ona bainoago apopilotzakontratua izango baita ${ }^{70}$. Baina ostalariak bere jabetzari eusten badio, arrotza ezingo da inoiz etxean bezala sentituko, beti izango baitu gogoan besteren etxean dagoela. Gauzak horrela, abegikortasuna ezinezko bihurtzen da: nork bere jabegoari uko eginez arrotza benetan etxean bezala sentiaraztea ez da abegi ona eskaintzea, kapitulatzea baizik; nork bere jabegoari eustea ere ez da abegi ona eskaintzea, apopilotza-kontratua baizik. Beraz, bada abegikortasunaren baitan barne-muga gaindiezin bat, pasabide zeharkaezin bat, aporia bat, alegia, abegikortasuna galarazi egiten duena $\mathrm{a}^{71}$.

Ezintasun hau, ordea, ez da berez negatiboa. Izan ere, abegikortasuna porrotera daraman itxituratzat hartu beharrean abegikortasuna gauzatzen hasteko aukera zabaltzen duen irekiduratzat hartu daiteke. Dekonstrukzioan ohi bezala, abegikortasuna, hain zuzen ere, barne-muga gaindiezinak gainditzean edota pasabide zeharkaezinak zeharkatzean datza. Horixe da ostalariak, abegikortasuna proiektu beharrezkoa eta ezinbestekoa den heinean utziezina ere badela gogoan hartuta, egin beharko lukeen ahalegina, ahalegina nola burutu ez dakien arren, emaitza beti ere abegikortasun mendratua izango dela dakien arren. Ostalariak bera eta arrotzaren arteko botere-hierarkia desegiten saiatu behar du, botere-hierarkiari nolabait eutsi beharrean badago ere. Ostalariak bere jabetza arrotzaren esku uzten saiatu behar du, jabetzari nolabait eutsi behar badio ere. Ostalariak abegikortasunetik haratago joaten saiatu behar du, harako biderik ezagutzen ez badu ere. Programa, erregela edota kalkulu oroz gabetuta egonik, ostalariaren erabakiak eroaldi uneak izan behar dira. Ez dago abegikortasunik ostalariaren eroaldi uneak berekin ez dakartzanik. Ez dago abegikortasunik pasabide zeharkaezin honen aporia zeharkatzeko beharrean ez dagoenik. Ez dago abegikortasunik abegikortasunetik haratago joateko beharrean ez dagoenik. Baina

68 - Puntu honetan, John D. Caputo-k Derrida-ren abegikortasun-nozioaz eginiko iruzkina jarraituko da batez ere. Ik. John D. Caputo, 'Community Without Community', in John D. Caputo (ed.), Deconstruction in a Nutshell. A Conversation with Jacques Derrida (New York: Fordham University Press, 1997), 106-24. orr 69 - Derrida-ren analisia hospitalitas (abegikortasun) hitz latindarraren azterketa etimologikoarekin hasten da. Hospitalitas hospes-etik eratortzen da (ostalari), zeina bere aldetik hostis (arrotz, arerio) eta pets (botere) hitzetatik eratortzen baita. Hau da, hospes (ostalari) bere botereari eutsi bitartean arrotzari ostatu ematen diona da. Ik. John D. Caputo, 'Community Without Community', 110. or.

70 - Abegikortasunaren azken asmo hori berritu egiten dugu bisitariari 'zure etxean zaude' esaten diogun bakoitzean.

71 - Derrida-k darabilen zentzuan, aporiak zera esan nahi du, pasabide zeharkaezina, hots, kurritu ahal delarik, kurritzeaz batera aurrera egin ezin deneko pasabidea, zeharkatzea eta oztopaturik geratzearen arteko muga zehatzezin bihurtzen duen esperientzia paradoxikoa, alegia. Ik., esaterako, Jacques Derrida, Apories. Mourir - s'attendre "aux limites de la vérité" (Paris: Galilée, 1996), 25-35. orr. passim. 
abegikortasuna ez da inoiz bere helmugara iristen. Zentzu honetan, ostalariaren abegikortasuna beti da eskasegia. Zentzu honetan, abegikortasuna beti dago gertatzeke. Baina ezinezkotasun hauxe da, hain zuzen ere, ostalariari etengabe gogorarazten diona barne-muga gaindiezinak gainditzeko eta pasabide zeharkaezinak zeharkatzeko duen betebeharra. Ezinezkotasun hauxe da abegikortasunaren egitasmoari irekirik eta bizi-bizirik eustea ahalbidetzen duena. Azken batean, abegikortasunaren ezinezkotasuna bere abalbide baldintza da ezintasun baldintza ere izan arren-, hots, abegikortasuna gertagarri bihurtzen duen baldintza -gertaezin ere bihurtu arren-

Abegikortasunaren analisi honek ondorio zuzenak dakartza komunitate edo nazioaren kontzeptuarentzat. Izan ere, abegikortasuna non bukatu behar den ezin zehazteak nazio bakoitzak beste nazioetatik babesteko behar dituen mugak non ezarri ezin zehaztea dakar berekin ${ }^{72}$. Muga horiek nazioaren kontzepturako funtsezkoak izateak honako ondorio hauxe dakar berekin: nazioaren funtsa zehatzezina da. Nazioak, beraz, abegikortasunari loturiko aporiaren antzeko bat agertzen du: nazioa abegikorregia bada bere identitatea galduko du; baina bere identitateari eusten badio, ez da behar beste abegikor izango. Nazioaren aporia bere mugei eusteaz batera muga horiek ireki behar izatean datza, mugak non eta nola jarri behar diren jakiteko programa, erregela edo kalkulu erabakigarririk ez dagoelarik. Ez dago, beraz, naziorik nazioa osatzen duen komunitatearen eroaldi uneak berekin ez dakartzanik. Ez dago naziorik bere aporiaren pasabide zeharkaezina zeharkatzeko beharrean ez dagoenik. Ez dago naziorik naziotasunetik haratago joateko beharrean ez dagoenik.

Laburbilduz, Derrida-k ez du komunitate, nazio edota kultur identitateen ezabaketa aldarrikatzen, baina komunitate, nazio eta kultur identitateak barnediferentzia batek markaturik egotea nahi du, beste(a)ren aurrean irekita egotea, horixe baita beren berezko izaera. Zentzu honetan, Derrida-k dioen bezala, 'batasun purua edo aniztasun purua -osotasuna edo batasuna bakarrik dagoenean eta aniztasuna edo zatikakotasuna bakarrik dagoenean- herioren sinonimo dira ${ }^{73}$. Komunitate, nazio edota kultur identitate baten barne-diferentzia onartzeak, bestalde, haren zehatzezintasuna onartu behar izatea dakar berekin, hau da, komunitatea, nazio edota kultur identitatea argi eta garbi zertan datzan ezin determinatu ahal izatea. Ez dago dudarik kolokan egote hau oso deserosoa gertatu behar dela mundu-ikuskera esentzialisten ziurtasunaren ondoan. Baina kolokan egote hori errealago, arduratsuago eta justuagoa da ziurtasuna baino, errealitatea ez baita esentziala, errealitatea diferentziala baita, errealitatea berez baitago kolokan. Antiesentzialismoa ez da, tamalez ulertu ohi den bezala, ezaxolakeriaren sinonimo. Kontrara, benetako erantzukizunaren, benetako konpromisoaren eragilea da. Erantzukizuna eta konpromisoa ez baitautza aldez aurretiko ezarritako programa, erregela edo kalkulu bati ahalik eta indartsuen eustean. Hori dogmatismoa baino ez da. Benetako erantzukizuna eta konpromisoa aporiaren esperientzian baino ez dira azaleratzen, programa, erregela eta kalkulu orok erantzun erabakigarririk eskaintzen ez digutenean, hain zuzen ere. Nazioaren aporia zeharkatzea da

72 - Komunitate hitzaren jatorri latindarraren azterketa etimologikoak argi erakusten du komunitatearen kontzeptua mugaren ideiari loturik sortu zela. Communio-k bizimodu komun edo partekatua adierazten $\mathrm{du}, \mathrm{com}+$ munus elkarketatik sortua, betebehar komunak izatea, ardura komunitarioak izatea, elkarri laguntza ematea. Baina communio-k defentsa komuna eraikitzea ere adierazten du, com (komuna) + munis (defentsa) elkarketatik sortua, alde guztietatik babestua egotea, mugak eraikitzea, alegia. Ik. John D. Caputo, 'Community Without Community', 107-8. orr.

73 - Jacques Derrida, 'The Villanova Roundtable', in John D. Caputo, Deconstruction in a Nutshell, ik. gorago, 13. or. Itzulpena neurea da. 
nazioaren arazoari erantzunik egokiena emateko modua, nazioa gehien indar dezakeen, nazioari leialen izan dakiokeen jarrera aurkitzeko bide bakarra. Justizia nazioarentzat, bai. Baina zehatzezina den justizia, beti ere etortzeke dagoen justizia. Ez dago beste biderik. Berez, ez dago biderik. Unean-unean irekitzen joan behar den bidea baino ez dago, programarik gabe, erregelarik gabe, kalkulurik gabe, eroaldiz eroaldi, justizia horizontean.

Ildo honetatik, Derrida-k dio:

Bada, dudarik gabe, desira menperaezin hau 'komunitate' bat osa dadin, baina baita komunitate horrek bere muga ezagut dezan ere -eta bere muga bere irekidura izan dadin: behin komunitateak uste duenean testua ulertu, bildu, interpretatu, gorde duela, orduan, testuak duen zerbaitek, erabat beste den testuaren baitako zerbaitek ihes egiten edo buru egiten dio komunitateari, bestelako komunitate bati dei egiten diolarik, komunitate presente baten oroimenean erabat baitaratua izateari itzuri egiten zaiolarik, beti ere ${ }^{74}$.

Hortaz, ez dago zertan arbuiaturik komunitatearen ideia, baina komunitatea Derrida-k 'beste komunitate bat' deitzen duena izan beharko litzateke, 'kuasikomunitate ireki bat', beti ere 'etortzeke dagoen komunitatea' dena, edota 'komunitaterik gabeko komunitatea ${ }^{75}$. Komunitatea eta nazioa ulertzeko modu hau da Soinujolearen semea-k gorpuztu mundu-ikuskeraren oinarri funtsezkoenetako bat, nobelaren hainbat motibotan ikus daitekeen bezala. Davidek gehien maite dituen pertsonekin osatu bizi-komunitateak berak ere, Daviden bizitzaren funtsa izan arren, gizakiok gure artean lor dezakegun bizi-batasun estuenaren adibide ederra izan arren, ez du batasun perfektua osatzen, ezin ditu nola edo halako distantzia galgarriak, bereizketa-gune eta barne-diferentzia aztoragarriak ekidin. David eta Josebaren arteko harremanak, kasu, anaitasunaren ideal desiragarria ederki islatzen du, bizi-kidetasunarena, elkarri baldintzarik gabe laguntza eman eta leial izatearena, alegia ${ }^{76}$. Halere, anaitasun hori ez da guztizko bat-egitea, Davidek, adibidez, ezkutatu egiten baitio Josebari memoriala idazten ari dela, bera nor izan den, bere egia, bere identitatea Josebari azaldu ezingo balio bezala ${ }^{77}$. David eta Mary Ann-en maitasun istorioak ere, perfektua, ideala iruditu arren, badu guztizko elkar ulertzea, erabateko bat-egitea galarazten duen unerik, bada nobelan Daviden egiak, identitateak Mary Ann-i ere ihes egiten diolako iradokizunik: Mary Ann-ek ez du ulertzen zergatik erabaki zuen Davidek memoriala euskaraz idaztea, jakinda modu horretan Mary Ann-ek ezingo zuela irakurri, ezingo zuela Daviden nortasunaren historiaren berri izan, ezingo zuela David guztiz ezagutu ${ }^{78}$. Davidek memoriala euskaraz idaztea erabakitzean, hizkuntz komunitatea lehenetsi zuen Mary Ann-ekin

\footnotetext{
74 - Frantsesezko jatorrizkoan: 'Il y a sans doute ce désir irrépressible qu'une "communauté » se forme mais aussi qu'elle sache sa limite - et que sa limite est son ouverture : une fois qu'elle croit avoir compris, recueilli, interprété, gardé le texte, alors quelque chose de celui-ci, quelque chose en lui de tout autre lui échappe ou lui résiste, qui appelle une autre communauté, qui ne se laisse jamais totalement intérioriser dans la mémoire d'une communauté présente.' Ik. Jacques Derrida \& François Ewald, " Une " folie " doit veiller sur la pensée»', elkarrizketa, in Elisabeth Weber (ed.), Jacques Derrida. Points de suspension. Entretiens (Paris: Galilée, 1992), 349-75. orr. (366. or.). Itzulpena neurea da.

75 - Frantsesezko jatorrizkoan: 'communauté sans communauté'. Ik. Jacques Derrida, Politiques de l'amitié (Paris: Galilée, 1994), 331. or.

76 - Josebak eginiko Daviden memorialaren berridazketa bion arteko anaitasuna berretsi eta omentzeko modutzat jo daiteke, berridazketa Anaiaren liburua titulatzeko Mary Ann-en iradokizunean islatzen den bezala. Ik. SS, 21. or.

77 - SS, 382. or.

78 - SS, 18-9. orr.
} 
osatu maitasun-komunitate txikiago baino estuagoaren aurrean ${ }^{79}$. Halere, Davidek ez zuen hizkuntz komunitate itxi, elebakar eta monolitikorik nahi, bere buruarentzat idatziriko epitafioa hiru hizkuntzatan -euskaraz, gaztelaniaz eta ingelesez- egoteak adierazten duen bezala ${ }^{80}$. Bestalde, hizkuntzak ez du gizabanakoen nazio-ideologia zertan determinaturik, Berlinoren anaia Antoniok gerrako frontetik bidaliriko euskarazko gutunean Davidek egiaztatu ahal izan zuenez $^{81}$. Ideologia-komunitateek ere ez dute zertan muga zeharkaezinetan banaturik egonik: Davidek eta bere aitak, bizitza osoan ideologikoki erabat banaturik egon ondoren, amaren ehorzketan elkarri emandako besarkadak hala iradokitzen $\mathrm{du}^{82}$. Honezaz gain, gizabanakoa den hori ez da kabitzen ideologiakomunitate zurrunek ezarritako arautegien barruan, gizabanakoaren eskubideak ezin dira jarri ideologia-komunitatearen beharren menpean abusuan erori gabe: David traidoretzat jo zuten ETAn bere amaren hiletetara joanez komandoa arriskuan jartzeagatik, baina ikuspegi horrek ez zuen Daviden eskubidea errespetatzen, ikuspegi horrek alienatu egiten zuen David, bitarteko huts, gauzaki bihurtzen zuen $^{83}$.

Xehetasun hauek guztiek Soinujolearen semea-k islatzen duen komunitate- eta nazio-ikuskeran dute sorburu eta ikuskera berau azpimarratzeko funtzioa dute. Ikuskera antiesentzialista honek, funtsean, komunitatea eta nazioa entitate zehatzezinak direla aldarrikatzen du, irekidura berezkoa eta ekidinezina duten entitateak direla. Horrela, ikuskera honek salatu egiten ditu komunitatea edo nazioari mugarri zorrotzak jartzen dizkien ikuskera oro, ikuspegi zurrunak, irrealak, desegokiak eta totalitarioak baino ez baitira. Nazioak ez dauka esentziarik. Zentzu horretan, ez dago argi eta garbi jakiterik nazioari leial izateko modurik egokiena zein den. 'Traizio' batzuk -Josebak eginikoa barne- nazioa zaintzeko, nazioari leial izateko modua izan daitezke. Nazioak arrotza behar du, eta behar horrek ezinezko

79 - Erabaki hau, berez, eroaldi unetzat jo daiteke, Derrida-ren erara: ba al zuen Davidek Mary Ann zein euskara bata bestearen aurrean lehenesteko arrazoi erabakigarririk? Ezin da guztiz justifikatu Davidek euskara aukeratu izana, baina, aldi berean, Davidek euskara aukeratu ez izana ere ezingo zen guztiz justifikatu. Zentzu honetan, euskal idazleei euskaraz zergatik idazten duten galdetzeak -gaur egun oraindik ere batez ere Euskal Herritik kanpo gertatu ohi zaien bezala- ez du inongo zentzurik. Galderak ez ditu galdera-egilearen aurreiritzi garratz, ozpindu eta guztiz arbuiagarriak baino islatzen.

80 - SS, 10. or.

81 - SS, 151. or.

82 - SS, 417. or. Besarkada honen esanahi sinbolikoa bistakoa da: arerio izandakoek beti dute eskura bakeak egiteko aukera. Halere, Atxagak bakeak egitea aukera bezala -are aukera desiragarria bezala ere, esan liteke- aurkezten duen arren, ez du adiskidetzea diferentziak guztiz ezabatuko lituzkeen egintza bezala aurkeztu nahi: Davidek aita besarkatu egiten du, baina memorialean gehien maite izan dituenei eginiko eskaintzan ez du aita inondik ere aipatzen. Diferentziek hor diraute, oroimenean. Adiskidetzea ez da arerio izandakoen arteko guztizko bat-egitea, adiskidetzeak ez du zertan berekin ekarririk norberak izandako jarrerari edo ideiei uko egin beharra.

83 - SS, 412-9. orr. Daviden jokaera traiziotzat jo zuena Carlos izan zen, komandoaren burua, alegia. Ik SS, 431. or. Eszena honen bidez, Atxagak ETAren nazio-ikuskera salatu egiten du gizabanakoaren eskubideak nazioaren beharren menpean jartzen dituen heinean. Salaketa hau bat dator Jean-François Lyotard-ek 'grands récits' direlakoei buruz eginikoarekin. Lyotard-ek 'grands récits' deitzen dituenak -osoko kontakizunak dei genitzakeenak euskaraz- mundu-ikuskera esentzialistetan oinarrituriko diskurtsoak dira, lehenik errealitatea osoki azal daitekeelako hipotesian oinarriturik lan egiten dutenak, eta bigarrenik errealitatea osoki azaltzen duten giltzarriak aurkitu dituztela aldarrikatzen dutenak. Lyotard-ek argudiatzen duenez, diskurtso horiek porrot egiten dute, hain zuzen ere, errealitatea ezin delako osoki azaldu, errealitateak ihes egiten diolako kontakizun globalizatzaile orori. Zentzu horretan diskurtso horiek kontakizun hutsak dira, errealitatearen interpretazioak, alegia, eta kontakizun horiek abusua, zapalketa eta totalitarismoa dakartzate berekin. Berdin gertatzen da ETAren nazio-ikuskerarekin, ez baitio gizabanakoari ezagutzen nazioaren beharrei ondo egokitzen ez zaien eskubide indibidualik. ETAren nazio-ikuskera osoko kontakizuna da, beraz. Ik. Jean-François Lyotard, La condition postmoderne. Rapport sur le savoir (Paris: Minuit, 1979). 
egiten du nazioa babesteko neurriak nolakoak eta zenbaterainokoak izan behar diren jakitea. Beraz, nazioa eredu zehatz, ongi mugaturiko eta behin betiko batean gorpuztea proposatzen duten ikuskera oro traizioa egiten ari zaio nazioari. Nazioak ezin du telos-ik izan, nazioaren helburua eta azken gauzapena ezin da aldez aurretik definituriko programa, erregela edo kalkulu baten baitan egon. Ez dago biderik unean-unean erabaki erabakiezinak hartzen joatea baino. Bide horixe da Josebak ETA uzteko erabakia hartuz, ETAri 'traizio' eginez hartu zuena, nazioa ahultzea beharrean nazioa sendotzea zuena helburu. Ez da zaila imajinatzen ETArik gabeko Euskal Herria sendoagoa izan litekeela hainbat eta hainbat alderditan, gizarteelkarbizitzak, euskarak berak, aldarrikapen politiko nazionalistek -are independentistek ere- edota Euskal Herriaren kanpo irudiak, besteak beste, baldintza hobeak aurki litzaketela sendotzeko, garatzeko, aurrera egiteko. Ez dago, jakina, hala gertatuko litzatekeela ziurtatzerik, bide horretarako ere ez baitago ez programa, ez erregela, ez kalkulu erabakigarri eta berme-emailerik. Horixe da, halere, herri honetako jende gehienak aspaldian egin nahi izan duen apustua. Horixe Atxagak egitea iradoki diguna ere. Euskal Herri/Hiriaren hobe beharrez.

\section{Bibliografia}

- Attridge, Derek, 'Introduction: Derrida and the Questioning of Literature', in Derek Attridge (ed.), Jacques Derrida. Acts of Literature (London \& New York: Routledge, 1992), 1-29. orr.

— Atxaga, Bernardo, 'Literatura fantastikoa', Jakin 25 (1982ko Urria-Abend.), 68-85. orr.

, 'Bihotzaren inbentarioa', El Diario Vasco. Zabalik (1989-6-7), 5. or.

, 'Obabakoak-en gainean', Enseiucarrean 5 (1990eko negua), 11-31. orr. , Soinujolearen semea (Iruña: Pamiela, 2003)

- Balkin, Jack M., 'Tradition, Betrayal, and the Politics of Deconstruction', Cardozo Law Review 11 (1990), lineako bertsioa, 1-18. or. < http://www.yale.edu/lawweb/ jbalkin/articles/tradit1.pdf > [2006ko ekainaren 21ean azkenekoz atzitua]

- Berlanga, Ángel, "Reflexiones sobre el "no matarás". Entrevista con el escritor vasco Bernardo Atxaga', Página/12 (2005-07-06)

<http://www.pagina12.com.ar/diario/cultura/index-2005-07-06.html> [2006ko ekainaren 8an azkenekoz atzitua]

- Caputo, John D., 'Community Without Community', in John D. Caputo (ed.), Deconstruction in a Nutshell. A Conversation with Jacques Derrida (New York: Fordham University Press, 1997), 106-24. orr.

- Critchley, Simon, 'The Other's Decision in Me (What Are the Politics of Friendship?)', in Christopher Norris \& David Roden (ed.), Jacques Derrida, 4 ale (London: Sage Publications, 2003), IV, 86-116. orr.

— Derrida, Jacques, Politiques de l'amitié (Paris: Galilée, 1994)

, Force de loi. Le "fondement mystique de l'autorité " (Paris: Galilée, 1994) 
— Derrida, Jacques \& Anne Berger, '« Dialangues »', elkarrizketa, in Elisabeth Weber (ed.), Jacques Derrida. Points de suspension. Entretiens (Paris: Galilée, 1992), 141-65. orr.

— Derrida, Jacques \& Derek Attridge, “This Strange Institution Called Literature”: An Interview with Jacques Derrida', itzul. Geoffrey Bennington \& Rachel Bowlby, in Derek Attridge (ed.), Jacques Derrida. Acts of Literature (London \& New York: Routledge, 1992), 33-75. orr.

— Derrida, Jacques \& François Ewald, “" Une " folie " doit veiller sur la pensée », elkarrizketa, in Elisabeth Weber (ed.), Jacques Derrida. Points de suspension. Entretiens (Paris: Galilée, 1992), 349-75. orr.

- Ferrater Mora, José, Diccionario de filosofía, 6. arg., 4 ale (Madril: Alianza, 1979), II

— Genette, Gérard, Figuras III (Bartzelona: Lumen, 1989)

— Iser, Wolfgang, 'El proceso de lectura: enfoque fenomenológico', itzul. Eugenio Contreras, in José Antonio Mayoral (ed.), Estética de la recepción (Madrid: Arco, 1987), 215-43. orr.

- Jauss, Hans Robert, La literatura como provocación, itzul. J. Godo (Barcelona: Península, 1976)

- Kortazar, Jon, "Soinujolearen semea” El hijo del acordeonista, de Bernardo Atxaga', Cuadernos de Alzate 32 (2005, 1. seihilekoa), 119-36. orr.

- Lyotard, Jean-François, La condition postmoderne. Rapport sur le savoir (Paris: Minuit, 1979)

- Lucy, Niall, Postmodern Literary Theory. An Introduction (Oxford: Blackwell, 1997)

- Miscevic, Nenad, 'Nationalism', in Edward N. Zalta (ed.), The Stanford Encyclopedia of Philosophy (2005eko neguko edizioa)

$<$ http://plato.stanford.edu/archives/win2005/ entries/nationalism> [2006ko ekainaren 19an azkenekoz atzitua]

- Olaziregi, Mari Jose, Bernardo Atxagaren irakurlea (Donostia: Erein, 1998)

, 'Paradisua hatz mamiekin ukituz: Bernardo Atxagaren Soinujolearen Semea', Egan LVII (2005-1/2), 63-76. orr.

- Renan, Ernest, Zer da nazioa?, itzul. Esteban Antxustegi (1882ko hitzaldia; Bilbo: Euskal Herriko Unibertsitatea, 2004)

— Smith, Robert, Derrida and Autobiography (Cambridge: Cambridge University Press, 1995) 